\title{
Fluid Inclusion and Oxygen Isotope Constraints on the Origin and Hydrothermal Evolution of the Haisugou Porphyry Mo Deposit in the Northern Xilamulun District, NE China
}

\author{
Qihai Shu ${ }^{1,2}$ and Yong Lai ${ }^{2}$ \\ ${ }^{1}$ State Key Laboratory of Geological Processes and Mineral Resources, School of Earth Sciences and Resources, \\ China University of Geosciences, Beijing 100083, China \\ ${ }^{2}$ Key Laboratory of Orogenic Belt and Crustal Evolution, School of Earth and Space Sciences, Peking University, Beijing 100871, China \\ Correspondence should be addressed to Qihai Shu; qshu@cugb.edu.cn
}

Received 14 July 2017; Accepted 2 October 2017; Published 1 November 2017

Academic Editor: Bin Chen

Copyright (C) 2017 Qihai Shu and Yong Lai. This is an open access article distributed under the Creative Commons Attribution License, which permits unrestricted use, distribution, and reproduction in any medium, provided the original work is properly cited.

\begin{abstract}
The Haisugou porphyry Mo deposit is located in the northern Xilamulun district, northeastern China. Based on alteration and mineralization styles and crosscutting relationships, the hydrothermal evolution in Haisugou can be divided into three stages: an early potassic alteration stage with no significant metal deposition, a synmineralization sericite-chlorite alteration stage with extensive Mo precipitation, and a postmineralization stage characterized by barren quartz and minor calcite and fluorite. The coexistence of high-salinity brine inclusions with low-salinity inclusions both in potassic alteration stage $\left(\sim 440^{\circ} \mathrm{C}\right)$ and locally in the early time of mineralization stage $\left(380-320^{\circ} \mathrm{C}\right)$ indicates the occurrence of fluid boiling. The positive correlations between the homogenization temperatures and the salinities of the fluids and the low oxygen isotopic compositions $\left(\delta^{18} \mathrm{O}_{\text {fluid }}<3 \%\right.$ of the syn- to postmineralization quartz together suggest the mixing of magmatic fluids with meteoric water, which dominated the whole mineralization process. The early boiling fluids were not responsible for ore precipitation, whereas the mixing with meteoric water, which resulted in temperature decrease and dilution that significantly reduced the metal solubility, should have played the major role in Mo mineralization. Combined fluid inclusion microthermometry and chlorite geothermometer results reveal that ore deposition mainly occurred between 350 and $290^{\circ} \mathrm{C}$ in Haisugou.
\end{abstract}

\section{Introduction}

The global molybdenum resource comes almost completely from porphyry-type deposits. In some of these deposits Mo is recovered as byproduct (i.e., porphyry $\mathrm{Cu}-\mathrm{Mo}( \pm \mathrm{Au})$ deposits), whereas, in others, the deposits are characterized by high abundances of Mo but virtually no $\mathrm{Cu}$ or $\mathrm{Au}$ (i.e., purely porphyry Mo deposits) such as the Climax-type deposits along the North American Cordillera [1-3]. China has more than half of the world's molybdenum metal [4], and many of the Mo deposits are similar to the Climax-type Mo deposits where molybdenite is almost the only sulfide [5]. Most of China's Mo deposits are located in the Qinling-Dabie orogenic belt in Central China (>8.5 Mt Mo metal $[4,6,7]$ ) and the eastern section of the Central Asian orogenic belt in northeastern China (>11 Mt Mo metal $[8,9])$. Unlike the Climax-type Mo deposits, which typically develop in backarc or intracontinental rifts and are associated with alkaline magmas [1], the porphyry Mo deposits in the Chinese Qinling-Dabie orogenic belt are related to high-K calcalkaline to shoshonitic magmas generated in syn- to postcollisional tectonic settings and therefore have been suggested to belong to a new class of Dabie-type (or collision-type) porphyry Mo deposits [7, 10-12]. However, recently Audétat and $\mathrm{Li}$ [13] argued that some of the previously proposed Dabie-type deposits can still be classified as Climax-type. Northeastern China has become the largest Mo ore region in China with the continuous discoveries of many porphyry 
Mo deposits in recent years, including the giant Chalukou (2.46 Mt Mo), Caosiyao (1.79 Mt Mo), Daheishan (1.09 Mt Mo), Luming (0.89 Mt Mo), and Diyanqin'amu (0.78 Mt Mo) porphyry Mo deposits [8]. These deposits are mainly Mo-only or Mo-dominant (with minor $\mathrm{Cu}$ ) deposits, and many of the deposits have Yanshanian (Jurassic to Early Cretaceous) ages and have been suggested to be related to the subduction or subsequent slab rollback of the Paleo-Pacific oceanic plate [8].

The nature and evolution of the fluids associated with porphyry Mo mineralization have been well documented through mineralogical, stable isotopic, melt and fluid inclusion studies $[2,3,7,10,12-14]$. It is generally accepted that both the Climax- and the Dabie-type Mo deposits are related to hydrothermal fluids with high contents of $\mathrm{F}$ and $\mathrm{H}_{2} \mathrm{O}$ but variable $\mathrm{CO}_{2}[7,13]$. Fluid boiling assemblages have been recognized in almost all porphyry Mo deposits [7, 10, 12, 13]. However, it was proposed that boiling is not the major factor controlling Mo precipitation for the Climax-type Mo deposits [13], although it has been suggested to have played a role in ore deposition for the Chinese Dabie-type Mo deposits by some Chinese geologists [7, 10, 12]. Till present the origin and evolution of fluids forming the porphyry Mo deposits in NE China have been rarely investigated [15-17], and the formation conditions and mechanisms remain unclear.

The newly discovered Haisugou porphyry Mo deposit located in the northern Xilamulun district, NE China, is a typical Mo-only deposit where $>95 \%$ of the sulfides are molybdenite $[8,18,19]$. The quartz veins or breccias with variable alterations prior to, synchronous to, and immediately after molybdenite precipitation are widely distributed within the ore-related granite and thus provide an excellent opportunity to investigate the fluids (as fluid inclusions hosted in quartz) throughout the hydrothermal evolution processes. The present study aims at tracing the genesis and the hydrothermal evolution leading to alteration, metal concentration, and formation of the Haisugou porphyry Mo deposit through detailed study of fluid inclusion microthermometry, oxygen isotope, and chlorite chemistry. In addition, a comparison is also made to reveal the similarities and differences between the Haisugou Mo deposit and other Mo deposits in China and worldwide.

\section{Regional Geology}

Northeastern China lies in the eastern section of the Central Asian orogenic belt, a major Phanerozoic orogenic belt that separated the Siberia Craton to the north and the Tarim and North China Cratons to the south [20]. In the easternmost part of the Central Asian orogenic belt, the prolonged evolution processes in Paleozoic including subduction, accretion, and final closure of the Paleo-Asian ocean along the Xilamulun-Changchun suture resulted in the amalgamation of several microcontinents and the formation of what is now NE China (Figure 1(a) [21]). The major blocks in NE China include, from north to south, the Erguna, Xing'an, Songliao, and Liaoyuan (also known as the Bainaimiao arc belt [22, 23]) terranes, which are bounded by a series of nearly Eor NE-trending faults including the Tayuan-Xiguitu suture, the Hegenshan-Heihe suture, and the Xilamulun-Changchun suture (Figure 1(a)). South to the Liaoyuan terrene is the northern margin of the North China Craton, which is separated from the Liaoyuan terrene by the Chifeng-Kaiyuan Fault (Figure 1(a)).

In Paleozoic, due to the southward subduction of the Paleo-Asian oceanic plate beneath the northern margin of the North China Craton, extensive subduction-related intrusions have been recognized in the region, forming a typical Andean-type continental margin [24, 25]. In Triassic, NE China went into a postcollisional intraplate evolution stage, as indicated by the occurrence of many alkaline rocks including ultramafic-syenite complexes, lamprophyres, and A-type granites [24-28]. Since Jurassic, NE China has been reactivated as a result of the westward subduction of the PaleoPacific oceanic plate $[23,29]$. The majority of the igneous rocks in NE China have Yanshanian ages [23, 29, 30] and have been attributed to the tectonic-thermal events related to the Paleo-Pacific plate subduction or subsequent slab rollback $[23,29]$. Coinciding with the Yanshanian magmatism, many hydrothermal ore systems formed in NE China, and many of them are Mo-dominant porphyry deposits [8, 9, 31], with less of skarn or epithermal types [31-34].

The Xilamulun district is named after the XilamulunChangchun suture, which divided the district into two parts (Figure 1(b)). The northern part (north of the suture) lies within the Songliao terrane, and the southern part (south of the suture) is part of the Liaoyuan terrane and the northern margin of the North China Craton (Figure 1(b)). There are two NNE-striking faults in this region, the Great Xing'an Range Fault in the west and the Nenjiang Fault in the east (Figure 1(b)), both of which are much younger than the Etrending Xilamulun-Changchun Fault; they were caused by the NW-directed subduction of the Paleo-Pacific plate [37]. The Xilamulun district contains Archaean gneiss and Paleozoic schist and marble in the south and Mesozoic sedimentary, intrusive, and volcanic rocks in the north (Figure 1(b)). The Xilamulun district has more than 25 Mo deposits, six of which are of Triassic ages, while the rest are of Late Jurassic to Early Cretaceous ages (Figure 1(b) [8]). The Haisugou deposit is located in the northern Xilamulun district, and the magmatism and Mo mineralization occurred in Early Cretaceous $[8,18]$.

\section{Deposit Geology}

3.1. General Characteristics. The Haisugou porphyry Mo deposit is about 50 kilometers to the north-northwest of the Lindong town, Barin Zuoqi in Inner Mongolia. It was discovered in 2010 and exploration is still on-going, and its resources have not been defined. The Haisugou granite is the major host to the orebodies (Figures 1(c) and 2), which outcrops less than $1 \mathrm{~km}^{2}$. The granite intrudes into the Lower Permian Qingfengshan Formation limestone and sandstone (Figure 1(c)). At the contact zone between the granite and the limestone, massive skarns have been recognized (Figure 2(d)); stratabound skarn zones also occur in hornfels [8]. However, there is no obvious mineralization on the skarns or within the sedimentary wallrocks. To the west of the mining area, there is a granodiorite stock (Biliutai granodiorite in 


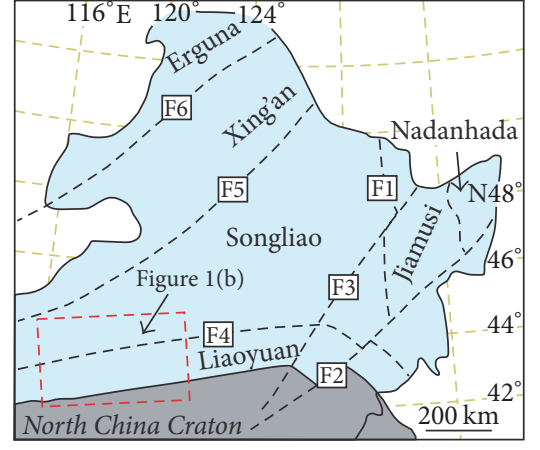

F1: Mudanjiang F4: Xilamulun-Changchun F2: Dunhua-Mishan F5: Hegengshan-Heihe F3: Yitong-Yilan F6: Tayuan-Xiguitu

(a)
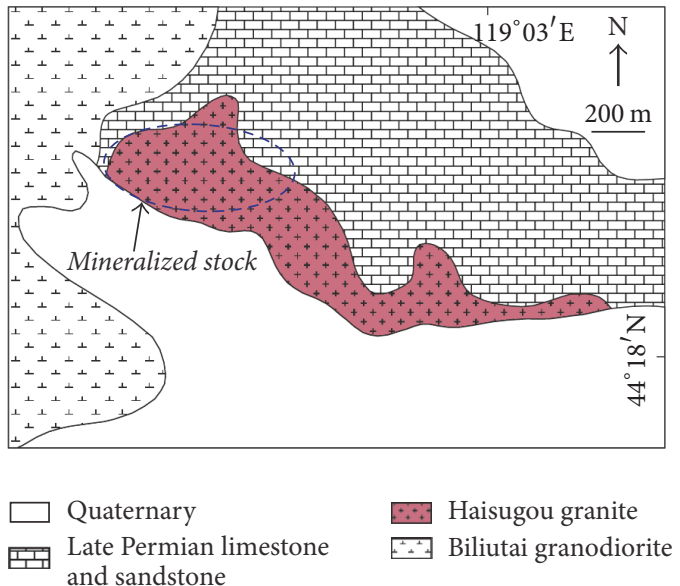

(c)

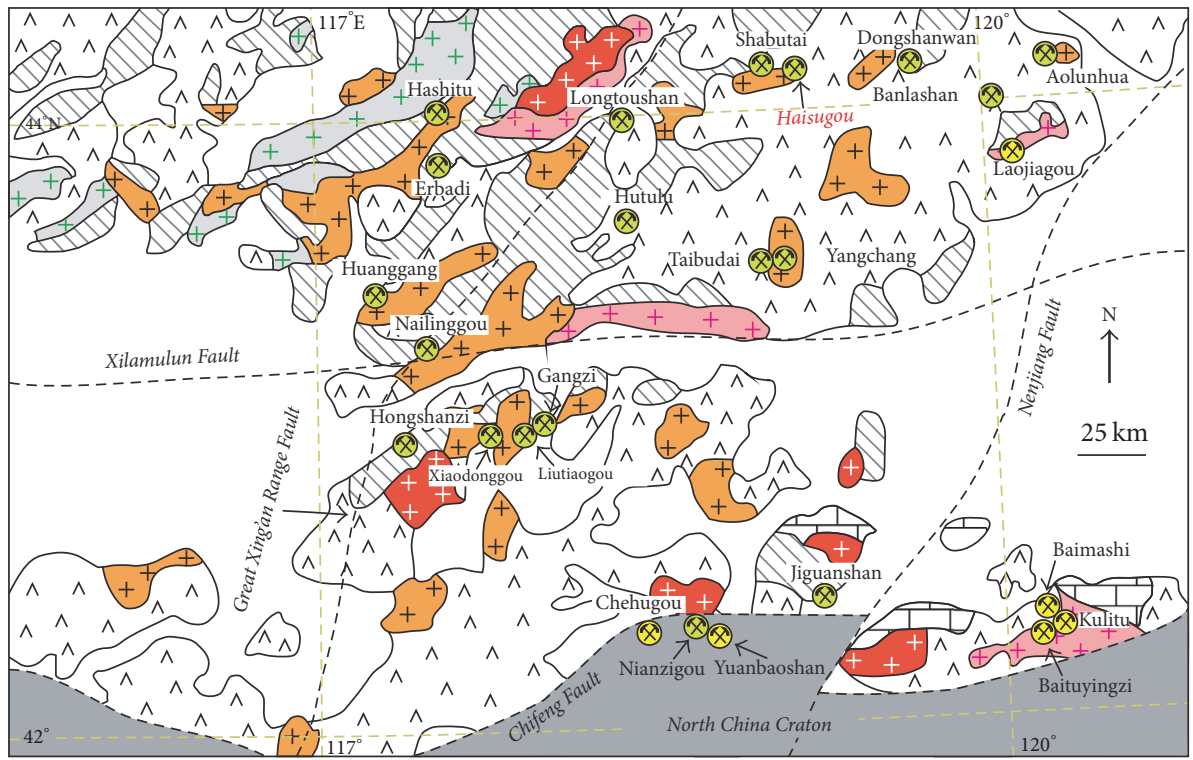

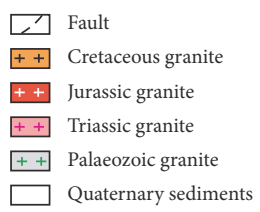

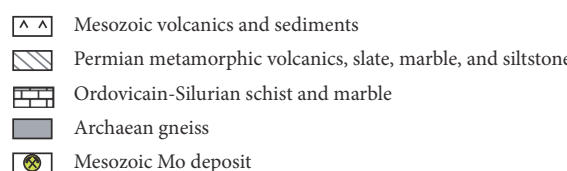

(b)

FIgURE 1: (a) Tectonic subdivisions of northeastern China and location of the Xilamulun district (from Wu et al. [21]). (b) Geological map of the Xilamulun district and the locations of major Mesozoic Mo deposits (from Shu et al. [8]). (c) Simplified geological map of the Haisugou porphyry Mo deposit (from Shu et al. [18]).

Figure 1(c)). This stock has Triassic ages [41] and has no obvious alteration and mineralization.

The Haisugou granite is porphyritic with fine-grained groundmass (Figures 2(a) and 2(b)). Plagioclase is the major phenocryst, which occupies $\sim 20$ vol\% of the rock, and it is typically zoned and rimed by K-feldspar. Other phenocrysts include biotite and amphibole (Figure 3(a)). The groundmass is composed of plagioclase, $\mathrm{K}$-feldspar, quartz, and biotite. Geochemically, the granite contains $68-75 \mathrm{wt} \% \mathrm{SiO}_{2}$,
12.6-15.1 wt $\% \mathrm{Al}_{2} \mathrm{O}_{3}, 3.1-4.1 \mathrm{wt} \% \mathrm{Na}_{2} \mathrm{O}$, and 3.3-4.7 wt $\%$ $\mathrm{K}_{2} \mathrm{O}$, belongs to the high- $\mathrm{K}$ calc-alkaline series, and is characterized by relatively high LREE, low HREE, depletion of $\mathrm{Ti}, \mathrm{Ba}$, and $\mathrm{Nb}$, and a moderate negative Eu anomaly [18]. Dioritic microgranular enclaves are distributed throughout the granite, which are generally several centimeters in diameter, and are rounded, ellipsoidal, or lenticular in shape (Figure 2(c)). Recent geochronological study indicated that the emplacement age of the granite is $137.6 \pm 0.9 \mathrm{Ma}$ (zircon 


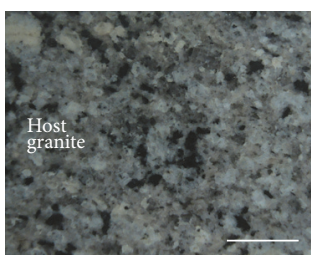

(a)

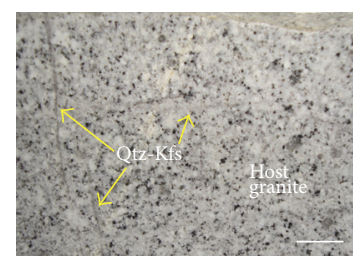

(b)

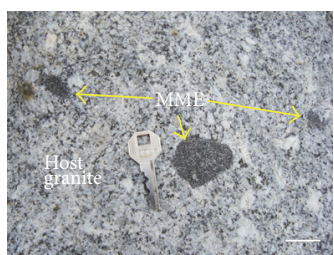

(c)

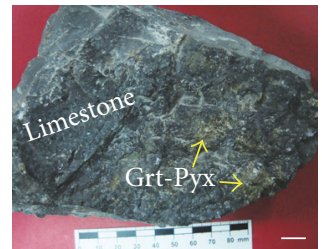

(d)

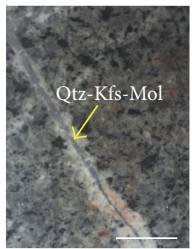

(e)

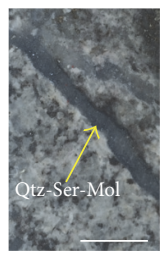

(f)

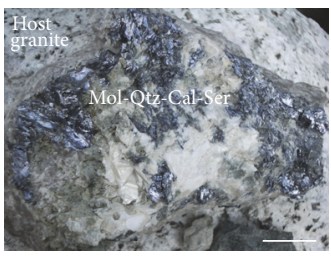

(g)

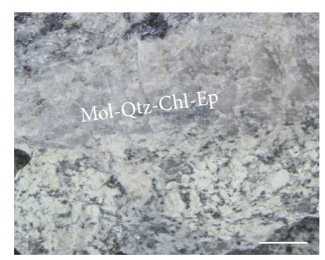

(h)

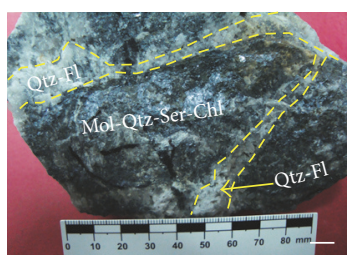

(i)

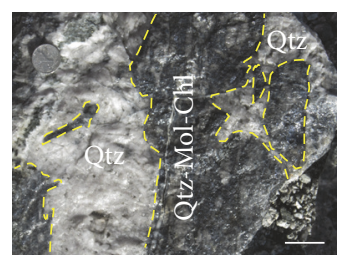

(j)

Figure 2: Hand-specimen photographs from the Haisugou Mo deposit showing the granite and the alteration and vein types from different hydrothermal stages. (a) Polished granite sample showing the major minerals including plagioclase, quartz, K-feldspar, biotite, and amphibole. (b) Barren quartz-K-feldspar veinlets in granite recording the earliest hydrothermal alteration in Haisugou. (c) Mafic microgranular enclaves in granite. (d) Garnet-pyroxene skarn in limestone in the contact zone between the country rocks and the granite. (e) Slightly mineralized P-stage quartz vein with K-feldspar halos. (f) S-stage quartz-sericite-molybdenite vein. (g) S-stage molybdenite-quartz-calcite-sericite vein. (h) S-stage quartz-molybdenite vein with chlorite and epidote halos. (i) Hydrothermal breccias containing clasts of S-stage molybdenitequartz-sericite-chlorite aggregates cemented by B-stage barren quartz and fluorite. (j) Hydrothermal breccias containing clasts of S-stage molybdenite-quartz-chlorite aggregates cemented by B-stage barren quartz. The scale bar is $1 \mathrm{~cm}$ in each photograph. Cal: calcite; Chl: chlorite; Ep: epidote; Fl: fluorite; Grt: garnet; Kfs: K-feldspar; MME: mafic microgranular enclave; Mol: molybdenite; Pyx: pyroxene; Qtz: quartz; Ser: sericite.

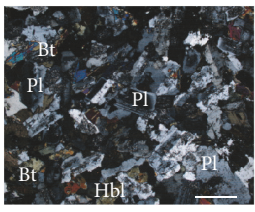

(a)

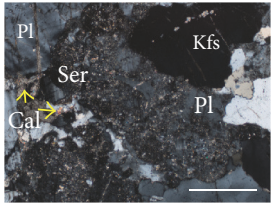

(b)

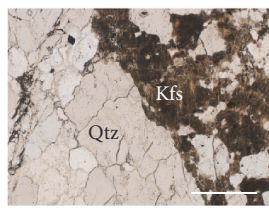

(c)

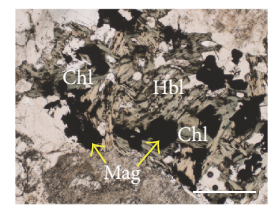

(d)

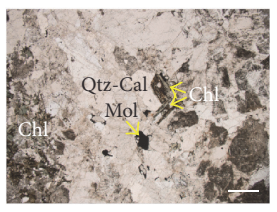

(e)

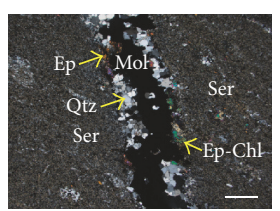

(f)

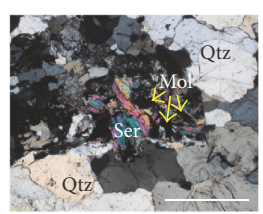

(g)

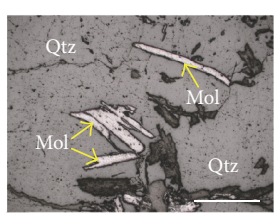

(h)

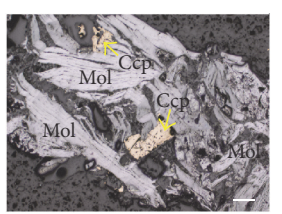

(i)

Figure 3: Representative photomicrographs from the Haisugou Mo deposit showing the alteration and mineralization in different hydrothermal stages. (a) Photomicrograph of the Haisugou granite showing the major phenocryst minerals. (b) Plagioclase of the granite altered to sericite and calcite. (c) P-stage barren quartz vein surrounded by K-feldspar halos. (d) Hornblende of the granite altered to magnetite and chlorite. (e) S-stage quartz-calcite-molybdenite vein with chlorite halos. (f) S-stage quartz-molybdenite-chlorite-epidote vein with sericite halos. (g) S-stage molybdenite-quartz-sericite vein. (h) Molybdenite flakes in S-stage quartz vein. (i) Molybdenite flakes and chalcopyrite in S-stage breccia ores. (a), (b), (f), and (g) were taken under crossed polarized light, (c), (d), and (e) under plane polarized light, and (h) and (i) under reflected light. The scale bar is $0.5 \mathrm{~mm}$ in each photomicrograph. Bt: biotite; Cal: calcite; Ccp: chalcopyrite; Chl: chlorite; Ep: epidote; Hbl: hornblende; Kfs: K-feldspar; Mag: magnetite; Mol: molybdenite; Pl: plagioclase; Qtz: quartz; Ser: sericite.

$\mathrm{U}-\mathrm{Pb}$ dating [18]) and the mineralization age is $136.4 \pm 0.8 \mathrm{Ma}$ (molybdenite Re-Os dating [8]). The two age datasets are well consistent within error, suggesting that the granite is the synmineralization intrusion.

3.2. Alteration and Mineralization. The Haisugou granite is hydrothermally altered and mineralized. Based on hand lens examination of field samples supplemented by petrographic observation of thin sections, a series of alteration types with various degrees of mineralization have been recognized (Figures 2 and 3). A simplified paragenetic sequence of the alteration and mineralization at Haisugou is shown in Figure 4.

The earliest alteration minerals are hydrothermal Kfeldspar and minor secondary biotite and magnetite. The Kfeldspar mainly occurs as halos surrounding barren quartz 


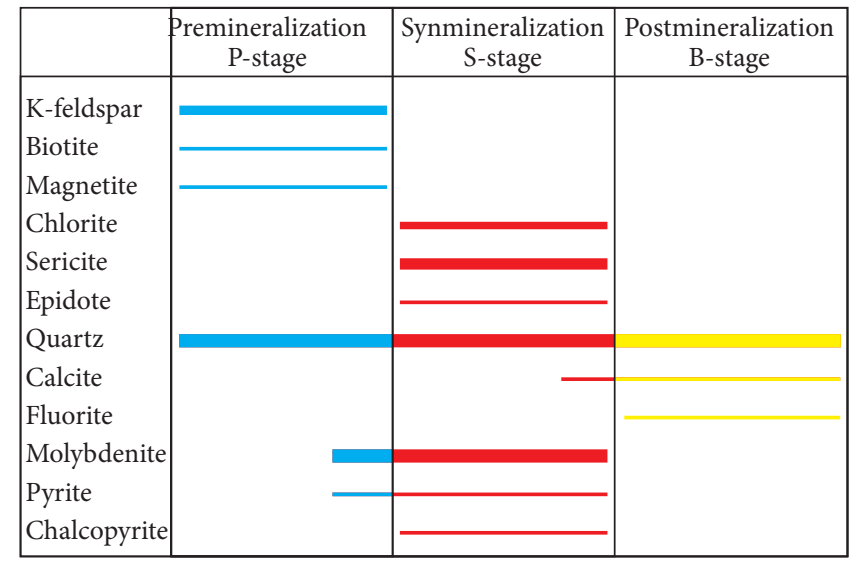

FIgURE 4: Schematic paragenetic sequence of the Haisugou Mo deposit.

veins (generally $<10 \mathrm{~mm}$ wide, Figures 2(b) and $3(\mathrm{c})$ ), although some molybdenite-bearing quartz veins $(1-5 \mathrm{~mm}$ wide) also have K-feldspar halos (Figure 2(e)). These two types of quartz veins with $\mathrm{K}$-feldspar halos are the main potassic alteration assemblages at Haisugou. In addition, hydrothermal K-feldspar veinlets $(<5 \mathrm{~mm}$ wide, without obvious quartz) are also common in the mineralized granite [8]. Hydrothermal biotites are rare but, when observed, they occur as halos along irregular barren quartz veinlets. Magnetites are also rare and can locally be found in the potassically altered barren quartz veins, or as emplacement of hornblende in the granite (Figure 3(d)).

The early potassic alteration is overprinted by later sericite-chlorite alteration. The general alteration assemblages are molybdenite-rich quartz-sericite \pm chlorite \pm epidote \pm calcite veins (Figures $2(\mathrm{f})-2(\mathrm{~h})$ and $3(\mathrm{~d})-3(\mathrm{~g})$ ) or quartzmolybdenite-chlorite breccias (Figures 2(i) and 2(j)). The veins are often seen to cut the potassically altered barren quartz veins. It is also common in the granite that plagioclase is altered to sericite \pm calcite (Figure $3(\mathrm{~b})$ ) and hornblende is replaced by chlorite (Figure $3(\mathrm{~d})$ ). This alteration stage is the main mineralization stage at Haisugou and directly controls bulk Mo mineralization. Sulfide minerals, mostly molybdenite with trace pyrite and chalcopyrite, occur mainly in these quartz veins (Figures 2(f)-2(h), 3(h) and 3(i)) with sericite \pm chlorite \pm calcite halos and to a lesser extent as disseminated grains in the granite. The quartz-sulfide veins are $<1$ to $\sim$ $10 \mathrm{~cm}$ wide (Figures 2(f)-2(h)). Breccia ores with centimetersized, angular-subangular clasts of quartz-molybdenitechlorite fragments cemented by late barren quartz have also been recognized (Figures 2(i) and 2(j)).

Barren quartz veins are also seen to postdate preexisting potassic and sericite-chlorite alterations (Figures 2(i) and $2(j))$. Unlike the barren quartz in the potassic alteration stage, these barren quartz veins are wider $(0.2-2 \mathrm{~cm})$ but have no obvious alteration halo. This stage barren quartz also occurs as fillings cementing the above-mentioned hydrothermal breccias (Figure $2(\mathrm{j})$ ). Other minerals including calcite and very rare fluorite are also seen in the barren quartz veins (Figure 2(i)), altogether indicating a relatively later and cooler fluid evolution stage and a postmineralization timing.
Based on the above observation, the alteration and mineralization of the Haisugou porphyry Mo deposit can be generally divided into three stages (Figure 4): an early potassic alteration stage (P-stage), a synmineralization sericitechlorite alteration stage (S-stage), and a postmineralization barren quartz stage (B-stage). The following text focuses on fluid inclusion and oxygen isotopic studies related to the quartz in these three different stages.

\section{Analytical Methods}

Altered granite and different quartz veins or breccias samples in Haisugou were collected for observation and analyses. For fluid inclusion study, the quartz samples representing the three hydrothermal evolution stages were selected and are summarized in Table 1. Prior to microthermometric analysis, a qualitative detection of the individual fluid inclusion compositions including vapor phase, liquid phase, and daughter minerals was carried out using a RM-1000 Laser Raman scanning spectrometer at Peking University. An excitation wave length of $514.5 \mathrm{~nm}$ was used as the laser source with a power of $22 \mathrm{~mW}$. The scanning range was $200-4000 \mathrm{~cm}^{-1}$. The spectral resolution was $\pm 2 \mathrm{~cm}^{-1}$ with a minimum diameter of the laser beam of $2 \mu \mathrm{m}$. Fluid inclusion microthermometric data were measured using an INSTEC HCS622XY programmable heating-cooling stage attached to a Nikon ECLIPSE LV100POL transmitted light microscope at Peking University. Stage calibration was carried out using synthetic fluid inclusions at the triple point of $\mathrm{CO}_{2}\left(-56.6^{\circ} \mathrm{C}\right)$ and the freezing point of pure water $\left(0.0^{\circ} \mathrm{C}\right)$. Estimated accuracy is $\pm 0.1^{\circ} \mathrm{C}$ for measurements of final ice-melting temperatures and within $4^{\circ} \mathrm{C}$ for halite dissolution and final homogenization temperatures. Heating/cooling rates were commonly restricted to $\sim 10^{\circ} \mathrm{C} / \mathrm{min}$ and reduced to $<1^{\circ} \mathrm{C} / \mathrm{min}$ near phase transformation. The salinity of the halite-bearing fluid inclusions was calculated from halite dissolution temperatures [42], and, for the liquid-vapor inclusions, the salinity was calculated from the final ice-melting temperatures [43]. All the salinity data are reported in weight percent $\mathrm{NaCl}$ equivalent (wt $\% \mathrm{NaCl}$ equiv). 


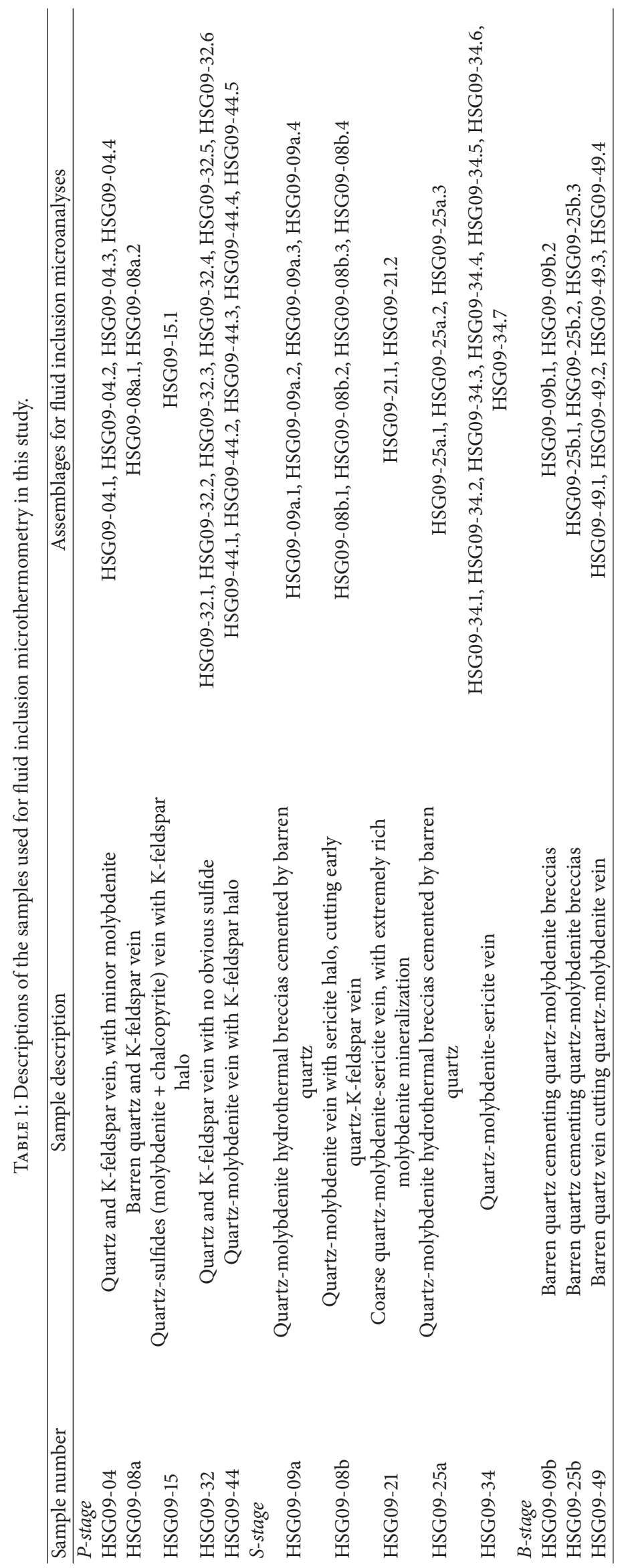




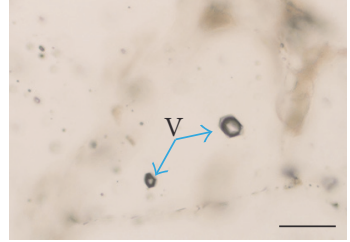

(a)

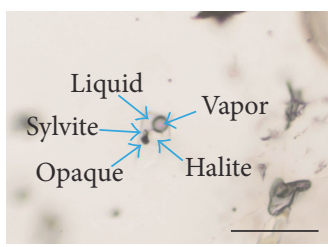

(e)

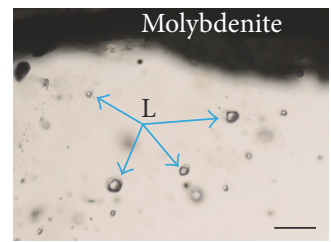

(i)

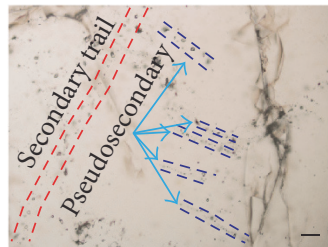

(b)

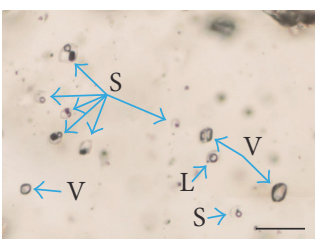

(f)

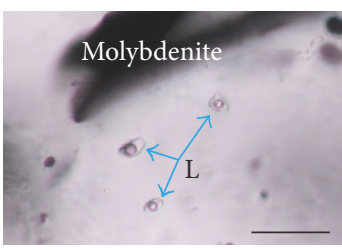

(j)

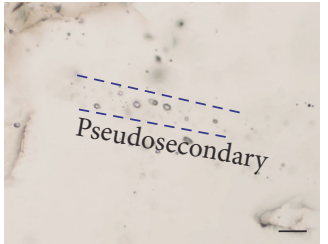

(c)

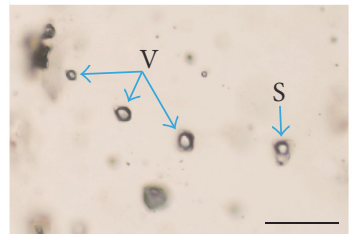

(g)

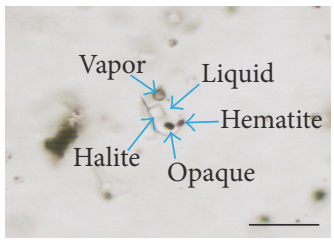

(k)

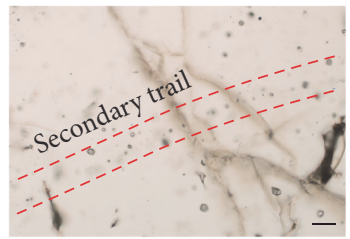

(d)

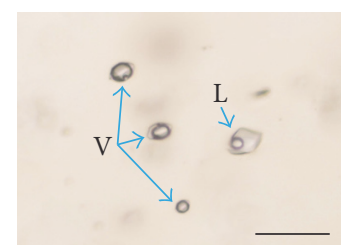

(h)

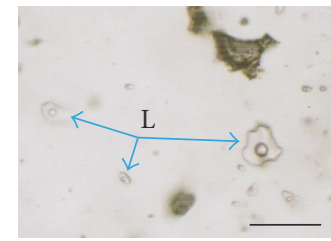

(l)

FiguRE 5: Representative photomicrographs of fluid inclusions hosted in quartz of different hydrothermal stages. (a) Primary V-type fluid inclusions in P-stage quartz. (b) Linear distributed pseudosecondary fluid inclusions (along intragrain fractures) and secondary fluid inclusions (cutting through quartz grain boundaries). (c) Pseudosecondary fluid inclusions along intragrain fractures. (d) Secondary trails of fluid inclusions crosscutting quartz boundaries. (e) A P-stage S-type fluid inclusion containing a liquid phase, a vapor phase, a halite, a sylvite, and an opaque mineral. (f) Coexisting S-type, V-type, and L-type inclusions in P-stage quartz, noting opaque minerals are common in all types of inclusions. (g) Coexisting S-type and V-type inclusions in S-stage quartz. (h) Coexisting L-type and V-type inclusions in S-stage quartz. (i) and (j) L-type fluid inclusions in S-stage molybdenite-bearing quartz. (k) A P-stage S-type fluid inclusion containing a liquid phase, a vapor phase, a halite, a hematite, and an opaque mineral. (l) B-stage L-type fluid inclusions. The scale bar is $30 \mu \mathrm{m}$ in each photomicrograph. $\mathrm{P}-$, S-, and B-stage refer to pre-, syn-, and postmineralization stage, respectively.

For oxygen isotope composition analysis, the quartz separation from the three different paragenetic stages and one magmatic hornblende sample as well as one magmatic quartz sample from the fresh granite were chosen (Table 1). The samples were first carefully selected under a binocular microscope ( $\sim \mathrm{g}$ for each sample) and crushed into 200 mesh and then reacted with $\mathrm{BrF}_{5}$ to liberate oxygen from the quartz separates. The resultant oxygen was converted to $\mathrm{CO}_{2}$ on a platinum-coated carbon rod, the isotopic composition of which was determined using a Finnigan MAT-253 mass spectrometer at the Stable Isotope Laboratory of Mineral Resources Institute, Chinese Academy of Geological Sciences. The isotopic data are reported relative to the Standard Mean Ocean Water (SMOW). The analytic precision is better than $0.2 \%$. The $\delta^{18} \mathrm{O}$ values of water in equilibrium with the hydrothermal quartz were calculated using the equation of [44] with the estimated average trapping temperatures of fluid inclusions in the same quartz samples. The $\delta^{18} \mathrm{O}$ values of water in equilibrium with the magmatic quartz and hornblende were calculated based on the fractionation factors given by Yong-Fei [45] and Matsuhisa et al. [46], respectively, assuming a magma crystallization temperature of $730^{\circ} \mathrm{C}$ as calculated using the hornblende geothermometer [47].
Chlorite is common in S-stage, which occurs either in molybdenite-bearing quartz veins (Type I chlorite, Figures $3(\mathrm{e})$ and $3(\mathrm{f})$ ) or as replacement of hornblende (Type II chlorite, Figure 3(d)). Major elements in individual chlorite grains of both types were determined using a JEOLJXA-8100 electron microprobe housed in Peking University. The beam current is $10 \mathrm{nA}$ and the spot size is $2 \mu \mathrm{m}$. For instrument calibration, several synthetic minerals, natural minerals, and relevant standard minerals were used. The estimated precision for each element was better than $\pm 2 \%$.

\section{Results}

5.1. Fluid Inclusion Petrography and Microthermometry. Fluid inclusions analyzed in this study are all hosted in quartz (Figure 5). In order to better understand the fluids exactly representing the three hydrothermal stages, only primary and pseudosecondary inclusions have been focused on according to the criteria given by Goldstein and Reynolds [48]. The primary inclusions were difficult to identify due to the lack of clear quartz growth zonation under transmitted light microscope. Nevertheless, a small number of the inclusions have been believed to be primary as they occur as isolated 


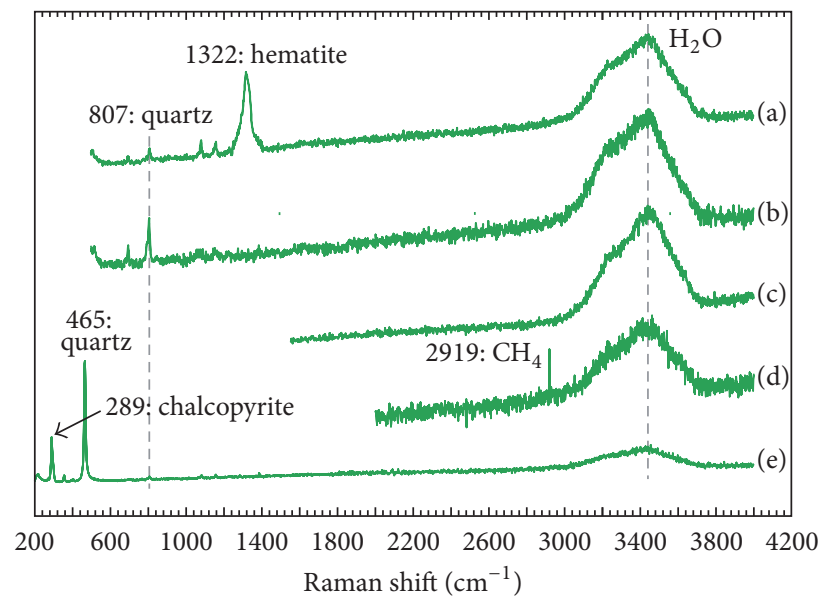

Figure 6: The Laser Raman spectra of fluid inclusions. The analyzed objects are the daughter mineral in a P-stage S-type inclusion (a), the liquid phase in a P-stage V-type inclusion (b), the vapor phase in a B-stage L-type inclusion (c), the liquid phase in a S-stage L-type inclusion (d), and the daughter mineral in a S-stage L-type inclusion (e). The results show that $\mathrm{H}_{2} \mathrm{O}$ is the dominant component of the liquid and vapor phases of all types of fluid inclusions in different stages (a-e), with very small amounts of $\mathrm{CH}_{4}(\mathrm{~d})$. Daughter minerals hematite (a) and chalcopyrite (e) were also identified. P-, S-, and B-stage refer to pre-, syn-, and postmineralization stage, respectively.

individuals with large size in relation to the size of the host quartz crystal (Figure 5(a)) [49]. Most of the fluid inclusions investigated in this study are pseudosecondary, which are linearly distributed along healed intragrain fractures (Figures $5(\mathrm{~b})$ and 5(c)). Secondary fluid inclusions are widespread and often align in trails and go through quartz grain boundaries (Figures 5(b) and 5(d)); they have an unknown origin in relation to the host quartz vein and therefore were avoided in this study. All the fluid inclusions were investigated following the approach of using fluid inclusion assemblages (FIAs, criteria of Goldstein and Reynolds [48]).

Based on the phases observed at room temperature and phase transformation upon heating, three major types of fluid inclusions have been defined in Haisugou. S-type inclusions at least contain a liquid phase, a vapor phase, and a halite (Figures $5(\mathrm{e})-5(\mathrm{~g})$ and $5(\mathrm{k})$ ). Sylvite and anhydrite are also present in some cases. Sylvite was distinguished from halite by its subcubic crystal (Figure 5(e)) whereas anhydrite was identified by its transparent anisotropic prisms. The bubble commonly fills $\sim 10$ to $30 \mathrm{vol} \%$ of the inclusions (Figures $5(\mathrm{e})-5(\mathrm{~g})$ and $5(\mathrm{k}))$. During heating, halite in most of these S-type inclusions dissolved before the homogenization of the vapor bubble into the liquid, although a few of them homogenized by final halite dissolution. L-type inclusions are composed of a liquid phase and a vapor phase (Figures $5(f)$, $5(\mathrm{~h})-5(\mathrm{j})$ and $5(\mathrm{l})$ ) and homogenized to the liquid phase upon heating. The vapor phase occupies $<50 \mathrm{vol} \%$ of the L-type inclusions. V-type inclusions are also composed of a liquid phase and a vapor phase (Figures $5(\mathrm{f})-5(\mathrm{~h})$ ) but would homogenize to vapor phase. V-type inclusions have a vapor bubble commonly occupying $>50 \mathrm{vol} \%$ of the total inclusion. Opaque daughter crystals are common in all types of inclusions hosted in P- and S-stage quartz (Figures 5(e)-5(k)) but could not always be identified. Nevertheless, some dark crystals were determined to be chalcopyrite and the red crystals (Figure 5(k)) were hematite based on Laser Raman spectroscopic analyses (Figure 6). Laser Raman analyses also revealed that the liquid and vapor phases of all types of fluid inclusions in different stages contain dominant $\mathrm{H}_{2} \mathrm{O}$ with none to very small amounts of $\mathrm{CH}_{4}$ but lack $\mathrm{CO}_{2}$ (Figure 6). The primary and pseudosecondary S-, L-, and V-type inclusions have similar shapes (negative or rounded to subrounded) and similar size (typically 5 to $20 \mu \mathrm{m}$ ) and often coexist in the same FIAs (Figures 5(f)-5(h)). The microthermometric results are presented as averages of assemblages with $1 \sigma$ uncertainty and are summarized in Table 2 and plotted in Figure 7.

In five quartz samples from the P-stage veins, 18 FIAs were measured. Most of the FIAs contain all three types of fluid inclusions (Table 2). The homogenization temperatures of the S-type fluid inclusions from 16 FIAs range from 363 to $504^{\circ} \mathrm{C}$, whereas the halite dissolution temperatures are between 267 and $382^{\circ} \mathrm{C}$, corresponding to salinities between 35.8 and $45.5 \mathrm{wt} \% \mathrm{NaCl}$ equiv (Figure 7). $10 \mathrm{~V}$-type FIAs have homogenization (to vapor phase) temperatures of $393-469^{\circ} \mathrm{C}$; final ice-melting temperatures from -3.1 to -0.5 correspond to salinities between 0.9 and $5.1 \mathrm{wt} \% \mathrm{NaCl}$ equiv (Figure 7). L-type inclusions from 17 FIAs have homogenization (to liquid phase) temperatures ranging from 333 to $469^{\circ} \mathrm{C}$, final ice-melting temperatures ranging from -7.3 to $-2.3^{\circ} \mathrm{C}$, and calculated salinities from 3.9 to $10.8 \mathrm{wt} \% \mathrm{NaCl}$ equiv (Figure 7). In the same FIAs, the coexisting S-, V-, and L-type fluid inclusions commonly yielded similar homogenization temperatures (Table 2 and Figure 7), indicative of fluid boiling in P-stage.

A total of 20 FIAs from S-stage molybdenite-quartz veins or breccias were measured. Most of the FIAs only contain L-type fluid inclusions, although S- and V-type inclusions have also been identified, respectively, in four assemblages (Table 2). L-type inclusions were present in all 20 FIAs and yielded homogenization temperatures of $325-382^{\circ} \mathrm{C}$ and final ice-melting temperatures of -6.5 to $-1.8^{\circ} \mathrm{C}$, corresponding 


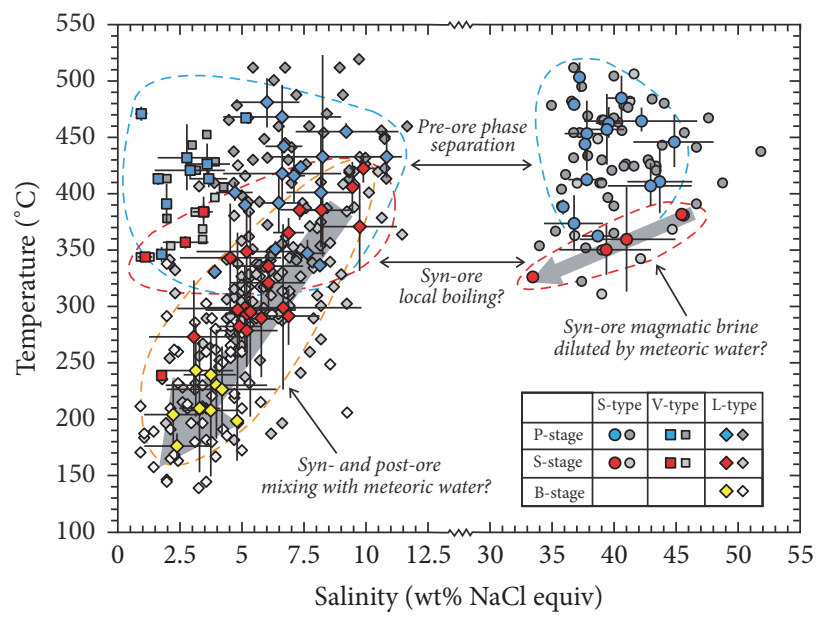

FIGURE 7: Homogenization temperature versus salinity plot of fluid inclusion assemblages (in color). Error bars are at $1 \sigma$ level. Individual fluid inclusion analyses in each assemblage are also plotted in black and white. P-, S-, and B-stage refer to pre-, syn-, and postmineralization stage, respectively.

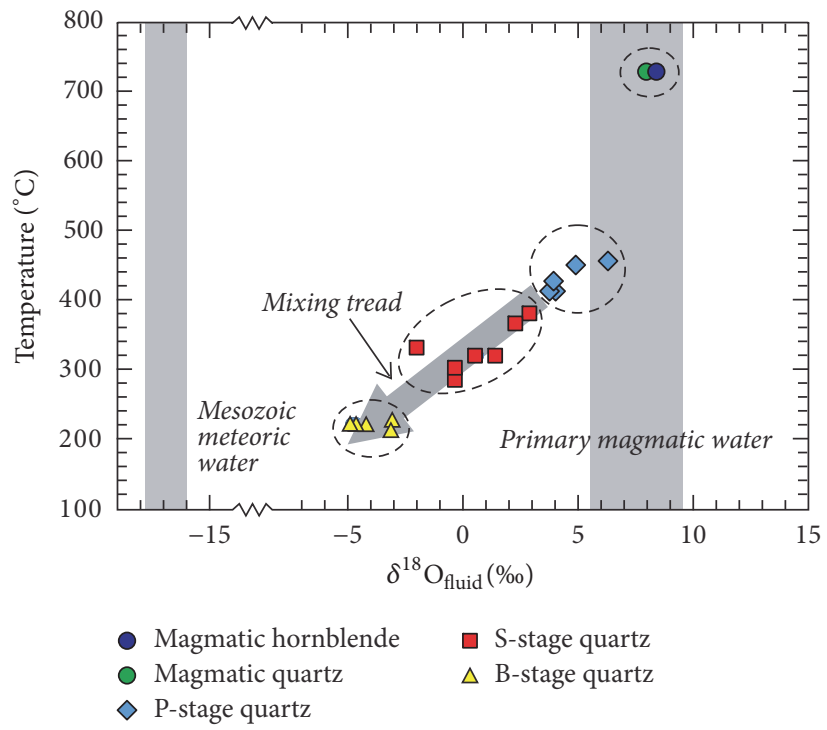

FIGURE 8: Homogenization temperature versus calculated oxygen isotopic value plot of magmatic hornblende and quartz, and hydrothermal quartz from three different paragenetic stages in Haisugou. The compositions of primary magmatic water [35] and the Mesozoic meteoric water in the northern Xilamulun district, northeastern China [36], are also shown for comparison. P-, S-, and B-stage refer to pre-, syn-, and postmineralization stage, respectively.

to calculated salinities of 3.0-9.9 wt\% $\mathrm{NaCl}$ equiv (Figure 7). Four FIAs containing S-type inclusions yielded homogenization temperatures of $355-407^{\circ} \mathrm{C}$, halite dissolution temperatures between 230 and $382^{\circ} \mathrm{C}$, and calculated salinities of 33.5 to $45.5 \mathrm{wt} \% \mathrm{NaCl}$ equiv (Figure 7). V-type fluid inclusions in four FIAs homogenized at $240-384^{\circ} \mathrm{C}$, with final ice-melting temperatures of -2.0 to $-0.6^{\circ} \mathrm{C}$ and calculated salinities of 1.1 to $3.4 \mathrm{wt} \% \mathrm{NaCl}$ equiv (Figure 7 ). The coexistence of different types of inclusions in some of the FIAs suggests that fluid boiling has occurred locally during Mo participation.

In B-stage, only L-type inclusions were recognized in all nine FIAs from three postmineralization barren quartz samples. They yielded homogenization temperatures between
177 and $244^{\circ} \mathrm{C}$, final ice-melting temperatures between -2.9 and $-1.3^{\circ} \mathrm{C}$, and calculated salinities between 2.2 and $4.8 \mathrm{wt} \%$ $\mathrm{NaCl}$ equiv (Figure 7).

5.2. Oxygen Isotope. The magmatic hornblende and quartz samples have measured $\delta^{18} \mathrm{O}$ values of 6.4 and $8.8 \%$, respectively, and the calculated $\delta^{18} \mathrm{O}$ values of the fluid in equilibrium with them are 8.4 and $7.9 \%$, respectively (Table 3 and Figure 8). For hydrothermal quartz, five samples from P-stage have measured $\delta^{18} \mathrm{O}$ values between 7.3 and $9.2 \%$, corresponding to calculated $\delta^{18} \mathrm{O}_{\text {fluid }}$ values between 3.8 and $6.3 \%$; the measured $\delta^{18} \mathrm{O}$ values of seven samples from $\mathrm{S}$ stage range from 3.7 and $7.4 \%$, corresponding to calculated 


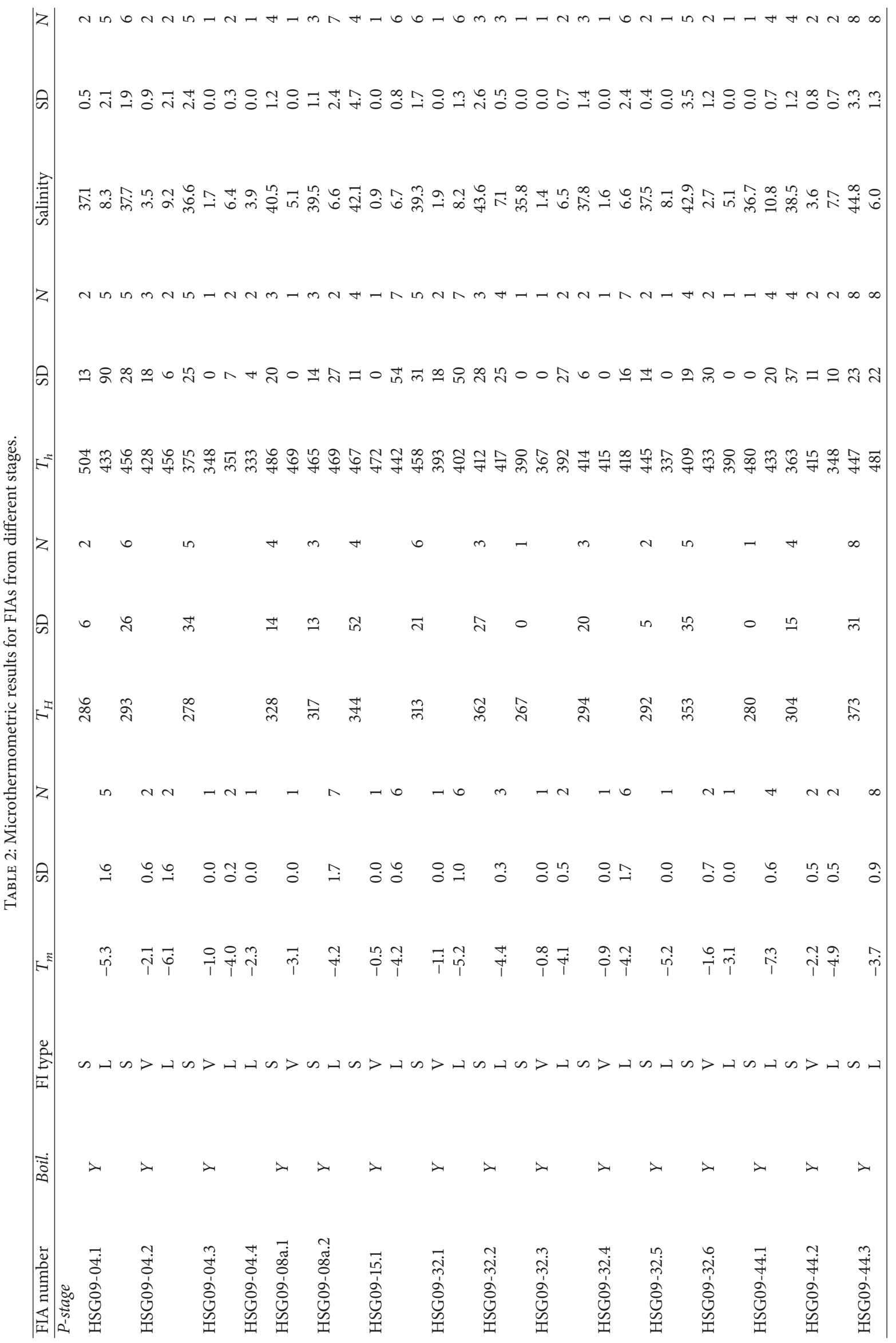




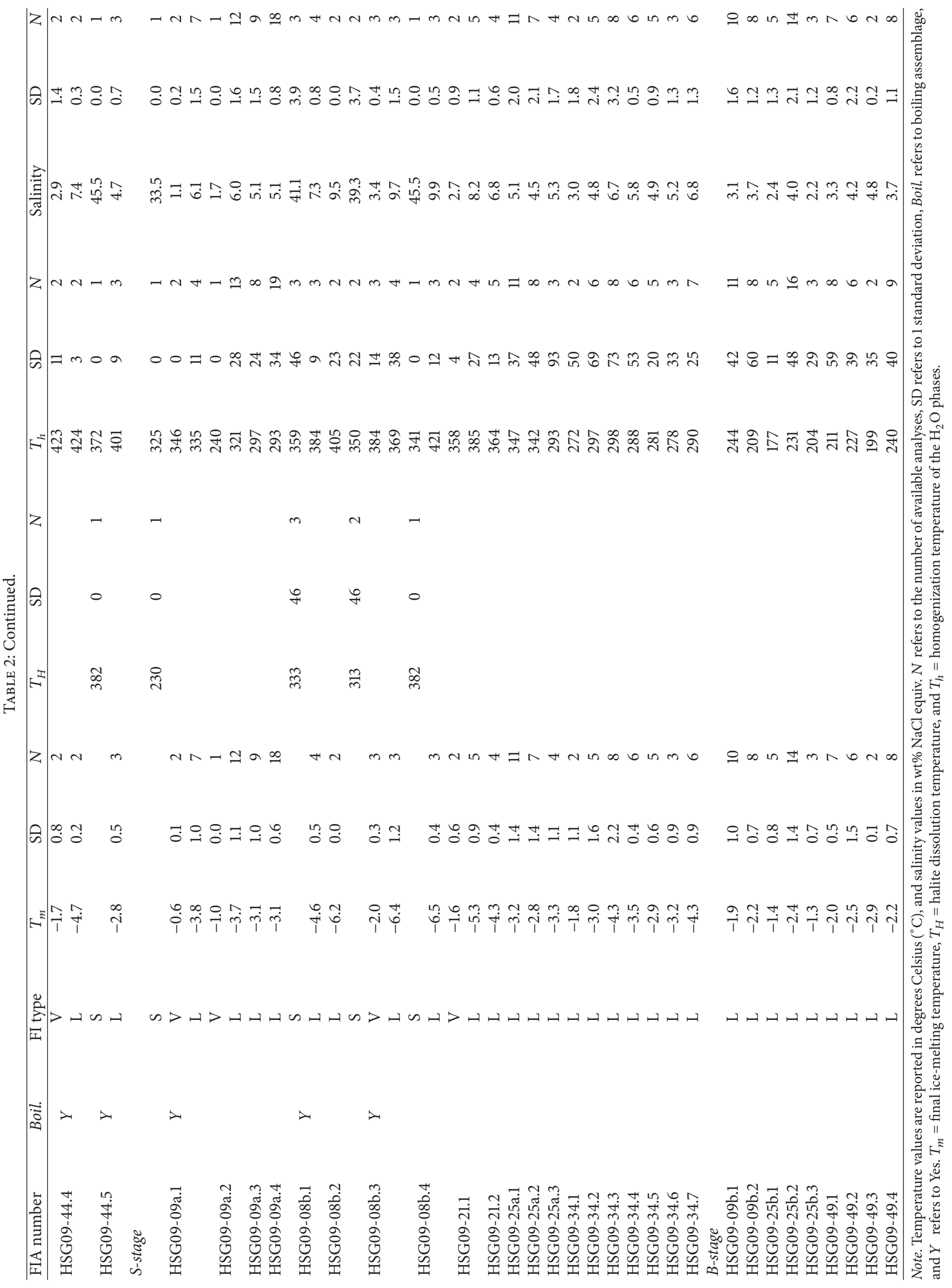




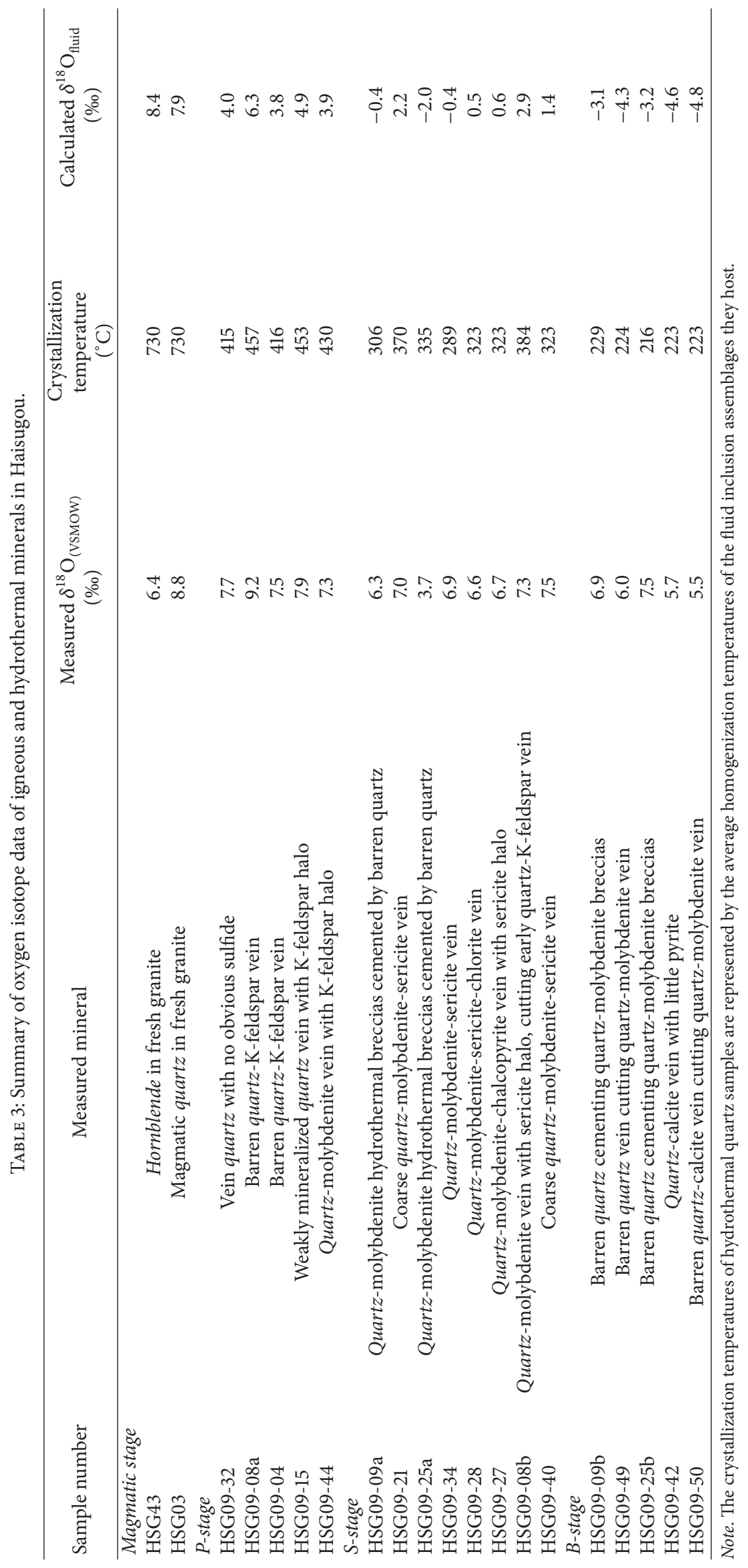




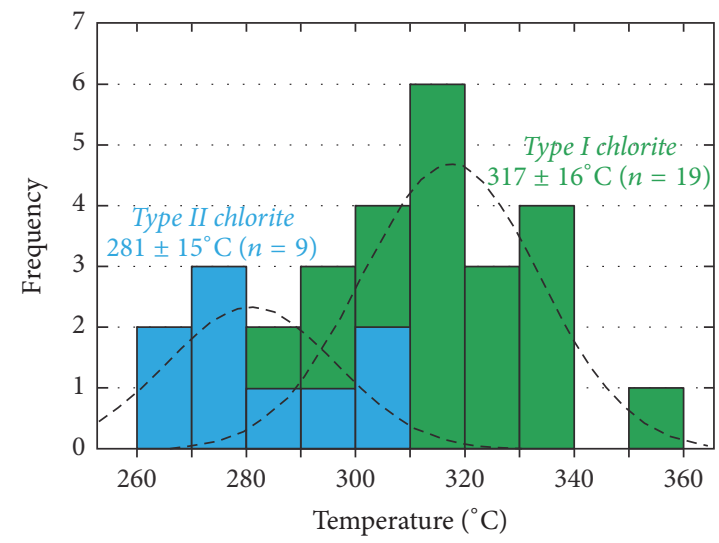

FIGURE 9: Histogram showing ranges of calculated temperature values of two types of chlorite in Haisugou.

$\delta^{18} \mathrm{O}_{\text {fluid }}$ values between -0.4 and $2.9 \%$; in B-stage, five samples have measured $\delta^{18} \mathrm{O}$ values between 5.5 and $7.5 \%$, corresponding to calculated $\delta^{18} \mathrm{O}_{\text {fluid }}$ values ranging from -4.8 to $-3.1 \%$ (Table 3 and Figure 8 ).

5.3. Chlorite Geothermometry. Chlorites analyzed at Haisugou are from the S-stage quartz-molybdenite veins (Type I chlorite, Figures 3(e) and 3(f)) and from the mineralized granite where chlorite replaces hornblende (Type II chlorite, Figure 3(d)). Chlorite compositions of both types are similar with $\mathrm{Fe} /(\mathrm{Fe}+\mathrm{Mg}$ ) ratios ranging from 0.49 to 0.55 (Table 4). Chlorite composition variations have been proposed to be closely related to the formation temperatures and thus it has been used as a geothermometer [50-52]. In this study we employed three different empirical equations to calculate the temperatures [38-40]. The results show that all three methods yielded highly consistent results with a standard deviation less than $5 \%$ of the average temperature value for each analysis (Table 4). Nine Type I chlorite analyses have average temperature values between 261 and $302^{\circ} \mathrm{C}$ (average $=281^{\circ} \mathrm{C}$, Figure 9), whereas 19 Type II chlorite analyses have average temperatures ranging from 285 to $352^{\circ} \mathrm{C}$ (average $=$ $317^{\circ} \mathrm{C}$, Figure 9).

\section{Discussion}

The results of this study indicate that the major Mo mineralization in the Haisugou porphyry deposit, NE China, was coeval with sericite-chlorite alteration but postdated earlier potassic alteration and predated the later barren quartz. The available fluid inclusion and oxygen isotopic data from different hydrothermal evolution stages allow us to interpret the fluid origin, the evolution from pre- through syn- to postmineralization fluids, and mechanisms of metal participation.

6.1. Fluid Nature and Sources. The volatile components of the fluids from all stages are mainly $\mathrm{H}_{2} \mathrm{O}$ with trace $\mathrm{CH}_{4}$ in some cases, but without any detectable $\mathrm{CO}_{2}$. The major daughter mineral in the S-type fluid inclusions is halite. It is therefore reasonable to come to the conclusion that the fluids belong to a dominantly $\mathrm{NaCl}-\mathrm{H}_{2} \mathrm{O}$ system. Other identified or inferred daughter crystals in fluid inclusions also include sylvite, anhydrite, hematite, and chalcopyrite (Figures 5 and 6). Taking into consideration the fact that the fluids were related to molybdenite deposition, we can plausibly confirm that the cations in the fluids include but are not limited to $\mathrm{Na}, \mathrm{K}, \mathrm{Ca}, \mathrm{Fe}, \mathrm{Cu}$, and $\mathrm{Mo}$, and the anions include $\mathrm{Cl}$ and $\mathrm{S}$. Fluorine is also present but is believed to be insignificant, as supported by the occurrence of very limited amounts of fluorite in the B-stage mineral assemblages (Figure 2(i)).

The formation of porphyry-type mineral deposits is typically associated with magmatic fluids, with or without involvement of meteoric water $[49,53,54]$. In Haisugou, fluid boiling in P-stage has been evidenced by the pervasive boiling assemblages where coexisting brines and lower-salinity fluids yielded similar homogenization temperatures (Figure 7 and Table 2). This confirms that the fluids in P-stage are directly a result of phase separation from exsolved magmatic fluid. Oxygen isotopic values of quartz samples from this stage are between 3.8 and $6.3 \%$, similar to but slightly lower than typical magmatic fluids (Figure 8) and also slightly lower than the primary magmatic minerals (hornblende and quartz) in Haisugou granite (Figure 8 and Table 3), suggesting that a subordinate contribution of meteoric water in this stage could not be ruled out.

In S-stage, boiling assemblages have also been recognized but only occur in part of the samples, in which S-type highsalinity inclusions are coexisting with low-salinity V-type and/or L-type inclusions, and they have comparable homogenization temperatures (Figure 7 and Table 2). It should be noted that the homogenization temperatures of the boiling assemblages are higher than most of the other assemblages in S-stage (Figure 7 and Table 2). The above observations suggest that fluid boiling has occurred, at least locally, during the early stage of mineralization. In addition, it is also notable that the homogenization temperatures of the four S-type FIAs in Sstage decrease along with the decreasing salinities (Figure 7), suggesting that the high-salinity fluids resulting in earlier fluid boiling should have been mixed with a fluid endmember with lower temperature and lower salinity before entrapment, which could most likely be meteoric water. In fact, most of the FIAs in the S-stage quartz samples only contain L-type 


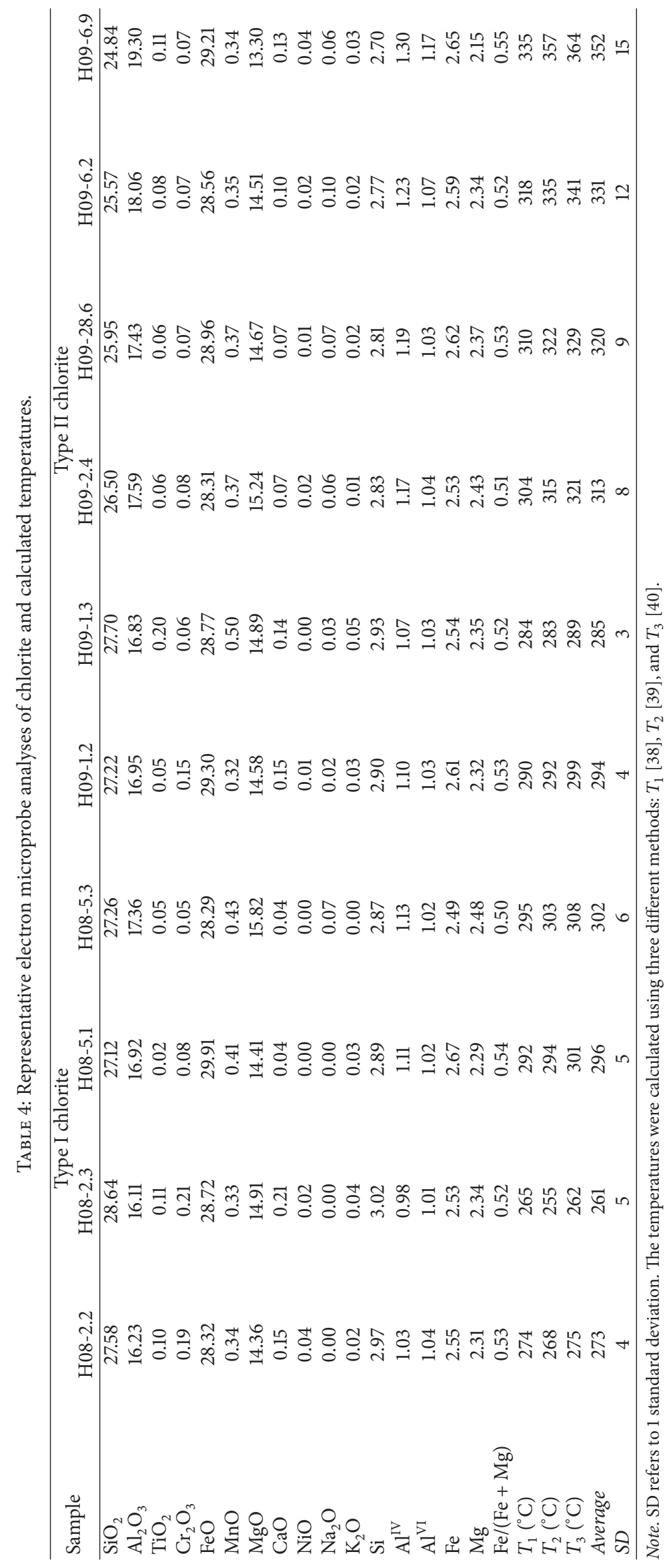


inclusions, and all the L-type FIAs display a well positive correlation between homogenization temperatures and salinities (Figure 7), implying that mixing of magmatic and meteoric fluids was common in this stage. Such ingression of meteoric water was also recorded by oxygen isotopic results of the S-stage quartz. In Figure 8 it is clear that all the S-stage quartz samples have oxygen isotopic compositions lower than magmatic fluid but significantly higher than the Mesozoic meteoric water in this region $\left(\delta^{18} \mathrm{O}=-16 \%\right.$ [36]) and that as temperatures drop from $\sim 400$ to $<300$, the oxygen isotope values decrease from 3.9 to $-0.4 \%$. All the above facts indicate that the magmatic fluid $\left(\delta^{18} \mathrm{O}>5 \%\right.$ ) was cooled and diluted by the meteoric water $\left(\delta^{18} \mathrm{O}=-16 \%\right.$ o during ore deposition.

The B-stage FIAs only contain L-type inclusions. Fluids in these assemblages have lower homogenization temperatures, lower salinities, and lower $\delta^{18} \mathrm{O}$ values (Figures 7 and 8), indicating that more meteoric water was added to the system, making the fluids much cooler and diluted, and mineralization ceased.

To sum up, the early premineralization (P-stage) fluids are dominantly magmatic and are results of fluid boiling; a small amount of meteoric water has been involved in the system. Boiling of magmatic fluids also occurred locally in the early time of the synmineralization S-stage; the majority of the fluids responsible for mineralization are admixtures of magmatic and meteoric water. The B-stage fluids have more portions of meteoric water, which postdated the major mineralization. Although it is widely accepted, based on stable isotope $[14,50,51,53]$ and fluid inclusion $[33,34,52$, 55] studies, that fluids that are related to porphyry/skarn mineralization have a dominantly magmatic fluid component $[34,53,56,57]$, in the Haisugou porphyry Mo deposit, however, meteoric water has been greatly involved, even since the early potassic alteration stage (P-stage).

6.2. Hydrothermal Evolution and Metal Deposition. The alteration and mineralization of the Haisugou porphyry Mo deposit are associated with at least three episodes of fluid activities. The fluid inclusion and oxygen isotopic data from this study suggest that different processes including fluid boiling and fluid mixing have occurred during the hydrothermal evolution. Fluid boiling occurred in the P-stage and locally the early time of the S-stage (Figure 7). In P-stage, fluid boiled at $\sim 440^{\circ} \mathrm{C}$, generating high-salinity brines (35.8 and $45.5 \mathrm{wt} \% \mathrm{NaCl}$ equiv, Table 2 ) and low-salinity fluids ( $\mathrm{V}$ - and L-type inclusions) with salinities $<12 \mathrm{wt} \% \mathrm{NaCl}$ equiv and leading to extensive potassic alteration, with limited molybdenite deposition. In S-stage, boiling also generated fluids with both high and low salinities (Figure 7 and Table 2), and both fluids were cooled and diluted by meteoric water, resulting in sericite and chlorite alteration, as well as extensive Mo participation. Such involvement of meteoric water also dominated the postmineralization B-stage evolution, and barren quartz formed as a consequence.

Several processes have been proposed to be the major factors controlling porphyry (or skarn)-style mineralization including decompression, phase separation (or boiling), cooling, interaction with rocks, and mixing with external waters
[33, 34, 53, 54, 58-64]. In Haisugou both fluid boiling and mixing with external (meteoric) water have occurred as proposed above. Decompression should also have occurred, which could be the direct cause of fluid boiling [64]. In addition, fluid cooling should be always undoubtedly a process throughout the hydrothermal evolution with the crystallization and cooling of the concurrent magmas and the incursion of meteoric water. Interaction with wallrocks could have also occurred, as has been recognized in many porphyry mineralization systems [61, 62], but our study could not confirm if this occurred in Haisugou.

As mentioned above, the P-stage boiling of magmatic fluid resulted in insignificant mineralization, implying that a simple fluid boiling process at $\sim 440^{\circ} \mathrm{C}$ would not lead to Mo participation. In S-stage, fluid boiling occurred in the earlier time with fluid temperature $>320^{\circ} \mathrm{C}$, but mixing with meteoric water dominated the whole mineralization process from $>400$ to $<250^{\circ} \mathrm{C}$, suggesting that fluid mixing might have played a key role in molybdenite deposition. Fluid mixing not only reduced the fluid temperature (Figure 7) and therefore reduced the metal solubility, but also caused dilution which would change the fluid salinity, acidity, and redox properties, altogether promoting metal deposition [65]. As for fluid boiling, however, it has been recently suggested that it is not a major cause for Mo precipitation in many porphyry Mo deposits [13]. This is because the initial supercritical (single-phase) fluid has a relatively low salinity (e.g., $\sim 7 \mathrm{wt} \% \mathrm{NaCl}$ equiv [2, 56, 59]), and the two-phase field is intersected on the vapor limb once boiling occurs; that is, brine will condense out of a vapor-like bulk fluid, rather than the other way around. In this case the condensation of small amounts of brine out of a vapor-like bulk fluid should not significantly influence the properties of the bulk system, and therefore fluid boiling in the porphyry Mo system is unlikely associated with metal precipitation [13]. In summary, metal deposition in Haisugou was mainly caused by mixing with meteoric water and related cooling, whereas boiling (and perhaps related decompression) seems less important to Mo mineralization.

Fluid mixing and mineralization were closely associated with sericite and chlorite alteration in Haisugou (Figures 2 and 3), which is consistent with previous understanding that meteoric water is necessary to produce sericite alteration $[35,66]$. Microthermometry of FIAs indicates that mineralization took place at $\sim 420$ to $\sim 240^{\circ} \mathrm{C}$, peak at $350-290^{\circ} \mathrm{C}$ (Figure 7 ). These data are also well consistent with the results from chlorite geothermometer, which gives a temperature range of $352-285^{\circ} \mathrm{C}$ for the chlorite from the S-stage molybdenite-bearing veins (Type I chlorite, Figure 9). However, it should be noted that the chlorite replacing hornblende in the Haisugou granite (Type II chlorite) has lower temperatures $\left(302-261^{\circ} \mathrm{C}\right.$, Figure 9), probably implying that such two types of chlorite were not formed at the same time and that the replacement of hornblende by chlorite took place slightly later than the formation of the quartz-chloritesericite-molybdenite veins. The similarity between the fluid inclusion homogenization temperatures and the calculated Type I chlorite temperatures suggests that Mo mineralization and related chlorite alteration in Haisugou mainly occurred 
at $350-290^{\circ} \mathrm{C}$. Since the $\mathrm{MoS}_{2}$ solubility below $400^{\circ} \mathrm{C}$ is extremely low, most porphyry Mo deposits are believed to mineralize at $\sim 400^{\circ} \mathrm{C}$ [64], significantly higher than the inferred mineralization temperatures in Haisugou. This probably can be attributed to the existence of other Mo complexes in the hydrothermal fluids in Haisugou that were capable of transporting Mo at relatively lower temperatures [64].

6.3. Comparison with Other Porphyry Mo Systems. One of the major differences in the Haisugou Mo deposit in NE China compared to the Chinese Dabie-type Mo deposits [7, 10, 12] is the absence of $\mathrm{CO}_{2}$ in the ore-forming fluids. In fact, in many investigated porphyry Mo deposits in NE China, $\mathrm{CO}_{2}$ has been reported to be either absent or very minor in amount [15-17]. This could probably be explained by the differences in ore-forming depths because in a deeper level the elevated pressure favors higher $\mathrm{CO}_{2}$ solubility in $\mathrm{NaCl}-\mathrm{H}_{2} \mathrm{O}$ fluids $[67,68]$. If this is true, then most of the NE China Mo deposits should have formed in shallower levels than the Mo deposits in the Chinese Dabie Belt, which is not reliable. An alternative explanation is that the magmatic-hydrothermal systems related to the NE China Mo deposits were originated from the subduction of the oceanic slabs, which must be infiltrated by seawater and definitely have lower $\mathrm{CO}_{2} / \mathrm{H}_{2} \mathrm{O}$ ratios compared to the intracontinental magmatic-hydrothermal systems with higher ratios of $\mathrm{CO}_{2} / \mathrm{H}_{2} \mathrm{O}$ that formed the Dabie-type Mo deposits [7, 10, 12].

Another dramatic difference is the lack of fluorine-rich minerals (e.g., fluorite) in Haisugou and many other Mo deposits in NE China $[15,17]$, which are, however, widespread in Dabie-type and Climax-type Mo deposits [3, 7, 13]. Although fluorite has been recognized in the B-stage veins (Figure 2(i)), it is very rarely present indicating $\mathrm{F}$ in the fluids is very low compared with the Dabie-type and Climaxtype Mo deposits, in which fluorite is one of the common alteration minerals $[3,7,13]$. The low-F contents in porphyry Mo systems have been attributed to a flat slab subduction setting, in which the major F-bearing mineral, phengite, would remain stable because it can be stable at depths of 70-300 km depending on the geotherm [69].

The Haisugou porphyry Mo deposit in NE China seems different from both the Dabie-type and the Climax-type Mo deposits in terms of the $\mathrm{CO}_{2}$ and $\mathrm{F}$ contents in the magmatichydrothermal systems. However, such low $\mathrm{CO}_{2}$ and $\mathrm{F}$ contents in NE China Mo deposits (including Haisugou) are very similar to the low-F type (also referred to as Endako-type, arc-related type, or subduction-type) porphyry Mo deposits along the west coast of the American continents [70, 71]. Moreover, the Haisugou deposit, as well as many other Mo deposits in NE China [16-19], is associated with calc-alkaline magmas, which is also consistent well with the low-F type porphyry Mo deposits. We therefore believe that many of the NE China Mo deposits can be classified to the low-F type. In addition, the low-F type porphyry Mo deposits commonly developed in active continental-margins [71, 72], which is also consistent with our recent understanding to many of the Yanshanian Mo deposits in NE China that have been proposed to be related to the Paleo-Pacific plate subduction or subsequent slab rollback [8].

\section{Conclusion}

(1) The hydrothermal evolution of the Haisugou porphyry Mo deposit in NE China can be divided into three stages: a premineralization P-stage characterized by potassic alteration with no significant metal deposition, a synmineralization S-stage characterized by extensive Mo precipitation with sericite and chlorite alteration, and a postmineralization Bstage characterized by barren quartz and minor calcite and fluorite.

(2) The fluids associated with the mineralization in Haisugou are dominantly of a $\mathrm{NaCl}-\mathrm{H}_{2} \mathrm{O}$ system with no detectable $\mathrm{CO}_{2}$. Fluid boiling occurred in P-stage (at $440^{\circ} \mathrm{C}$ ) and locally in the early time of the S-stage $\left(380-320^{\circ} \mathrm{C}\right)$, resulting in the coexistence of high-salinity brines with lowsalinity fluids. Mixing with meteoric water dominated the whole mineralization process from $>400$ to $<250^{\circ} \mathrm{C}$ and continued to postmineralization B-stage, as indicated by the positive correlations between the homogenization temperatures and the fluid salinities and between the homogenization temperatures and oxygen isotopic compositions of the hydrothermal quartz.

(3) Mixing and related fluid cooling could be the most likely controlling factors for Mo mineralization in Haisugou, whereas fluid boiling seemed less important. The Mo deposition took place at $\sim 420$ to $\sim 240^{\circ} \mathrm{C}$ and mainly between 350 and $290^{\circ} \mathrm{C}$ based on fluid inclusion microthermometry and chlorite geothermometer.

(4) The Haisugou deposit, as well as many other Mo deposits in NE China, is different from the Dabie-type or Climax-type porphyry Mo deposits in terms of the low $\mathrm{CO}_{2}$ and $\mathrm{F}$ contents. It is similar to the low-F type Mo deposits that developed in arc settings, which also confirms the previous understanding that the formation of many of the Yanshanian Mo deposits in NE China, including Haisugou, is related to the Paleo-Pacific plate subduction or subsequent slab rollback.

\section{Conflicts of Interest}

The authors declare that they have no conflicts of interest.

\section{Acknowledgments}

This paper was supported by National Natural Science Foundation of China (Grant no. 41390443). The authors thank Chao Wang and Yi Sun for help in the field and Jinyu Liu for assistance with data processing.

\section{References}

[1] R. B. Carten, W. H. White, and H. J. Stein, "High-grade graniterelated molybdenum systems: Classification and origin," in Mineral deposits modelling, Geological Association of Canada, Special Paper, R. V. Kirkham, W. D. Sinclair, R. I. Thorpe, and J. M. Duke, Eds., vol. 40, pp. 521-554, 1993.

[2] L. M. Klemm, T. Pettke, and C. A. Heinrich, "Fluid and source magma evolution of the questa porphyry Mo deposit, New 
Mexico, USA," Mineralium Deposita, vol. 43, no. 5, pp. 533-552, 2008.

[3] A. Audétat, "Compositional evolution and formation conditions of magmas and fluids related to porphyry mo mineralization at Climax, Colorado," Journal of Petrology, vol. 56, no. 8, Article ID egv044, pp. 1519-1546, 2014.

[4] J. W. Mao, F. Pirajno, J. F. Xiang et al., "Mesozoic molybdenum deposits in the east qinling-dabie orogenic belt: characteristics and tectonic settings," Ore Geology Reviews, vol. 43, no. 1, pp. 264-293, 2011.

[5] Q. Zeng, J. Liu, K. Qin et al., "Types, characteristics, and timespace distribution of molybdenum deposits in China," International Geology Review, vol. 55, no. 11, pp. 1311-1358, 2013.

[6] N. Li and F. Pirajno, "Early Mesozoic Mo mineralization in the Qinling Orogen: an overview," Ore Geology Reviews, vol. 81, pp. 431-450, 2017.

[7] Y.-J. Chen, P. Wang, N. Li, Y.-F. Yang, and F. Pirajno, "The collision-type porphyry Mo deposits in Dabie Shan, China," Ore Geology Reviews, vol. 81, pp. 405-430, 2017.

[8] Q. Shu, Z. Chang, Y. Lai, Y. Zhou, Y. Sun, and C. Yan, "Regional metallogeny of Mo-bearing deposits in Northeastern China, with new Re-Os dates of porphyry Mo deposits in the northern Xilamulun district," Economic Geology, vol. 111, no. 7, pp. 17831798, 2016.

[9] Y.-J. Chen, C. Zhang, P. Wang, F. Pirajno, and N. Li, “The Mo deposits of Northeast China: a powerful indicator of tectonic settings and associated evolutionary trends," Ore Geology Reviews, vol. 81, pp. 602-640, 2017.

[10] N. Li, T. Ulrich, Y.-J. Chen, T. B. Thomsen, V. Pease, and F. Pirajno, "Fluid evolution of the Yuchiling porphyry Mo deposit, East Qinling, China," Ore Geology Reviews, vol. 48, pp. 442-459, 2012.

[11] M. Mi, Y.-J. Chen, Y.-F. Yang et al., "Geochronology and geochemistry of the giant Qian'echong Mo deposit, Dabie Shan, eastern China: implications for ore genesis and tectonic setting," Gondwana Research, vol. 27, no. 3, pp. 1217-1235, 2015.

[12] Y.-F. Yang, Y.-J. Chen, F. Pirajno, and N. Li, "Evolution of ore fluids in the donggou giant porphyry Mo system, East Qinling, China, a new type of porphyry Mo deposit: evidence from fluid inclusion and H-O isotope systematics," Ore Geology Reviews, vol. 65, no. 1, pp. 148-164, 2015.

[13] A. Audétat and W. Li, "The genesis of climax-type porphyry Mo deposits: insights from fluid inclusions and melt inclusions," Ore Geology Reviews, vol. 88, pp. 436-460, 2017.

[14] J. L. Hannah and H. J. Stein, "Oxygen isotope compositions of selected laramide-tertiary granitoid stocks in the Colorado Mineral Belt and their bearing on the origin of climax-type granite-molybdenum systems," Contributions to Mineralogy and Petrology, vol. 93, no. 3, pp. 347-358, 1986.

[15] Q. H. Shu, L. Jiang, Y. Lai, and Y. H. Lu, "Geochronology and fluid inclusion study of the Aolunhua porphyry $\mathrm{Cu}-\mathrm{Mo}$ deposit in Arhorqin area, inner Mongolia," Acta Petrologica Sinica, vol. 25, no. 10, pp. 2601-2614, 2009.

[16] H. Wu, L. Zhang, F. Pirajno et al., “The Jiguanshan porphyry Mo deposit in the Xilamulun metallogenic belt, northern margin of the North China Craton, U-Pb geochronology, isotope systematics, geochemistry and fluid inclusion studies: Implications for a genetic model," Ore Geology Reviews, vol. 56, pp. 549-565, 2014.

[17] Y. Zhou, Y. Lai, Q. Shu, Y. Sun, J. Xu, and Y. Liang, "Geochronology and fluid inclusion study of the Shabutai porphyry Mo deposit, Inner Mongolia," Ore Geology Reviews, vol. 81, pp. 745759, 2017.

[18] Q. Shu, Y. Lai, C. Wang, J. Xu, and Y. Sun, "Geochronology, geochemistry and Sr-Nd-Hf isotopes of the Haisugou porphyry Mo deposit, northeast China, and their geological significance," Journal of Asian Earth Sciences, vol. 79, pp. 777-791, 2014.

[19] Q. Shu, Y. Lai, Y. Zhou, J. Xu, and H. Wu, "Zircon U-Pb geochronology and $\mathrm{Sr}-\mathrm{Nd}-\mathrm{Pb}-\mathrm{Hf}$ isotopic constraints on the timing and origin of Mesozoic granitoids hosting the Mo deposits in northern Xilamulun district, NE China," Lithos, vol. 238, pp. 64-75, 2015.

[20] A. M. C. Seng, B. A. Natalin, and A. M. C. Sengör, "Paleotectonics of Asia: fragments of a synthesis," in The Tectonic Evolution of Asia, A. Yin and T. M. Harrison, Eds., pp. 486-640, Cambridge University Press, 1996.

[21] F.-Y. Wu, D.-Y. Sun, W.-C. Ge et al., "Geochronology of the Phanerozoic granitoids in northeastern China," Journal of Asian Earth Sciences, vol. 41, no. 1, pp. 1-30, 2011.

[22] K. D. Tang and Z. Yan, "Regional metamorphism and tectonic evolution of the Inner Mongolian suture zone," Journal of Metamorphic Geology, vol. 11, no. 4, pp. 511-522, 1993.

[23] S.-H. Zhang, Y. Zhao, H. Ye, J.-M. Liu, and Z.-C. Hu, "Origin and evolution of the Bainaimiao arc belt: Implications for crustal growth in the southern Central Asian orogenic belt," Bulletin of the Geological Society of America, vol. 126, no. 9-10, pp. 1275-1300, 2014.

[24] S.-H. Zhang, Y. Zhao, B. Song et al., "Contrasting late carboniferous and late permian-middle triassic intrusive suites from the northern margin of the North China craton: geochronology, petrogenesis, and tectonic implications," Bulletin of the Geological Society of America, vol. 121, no. 1-2, pp. 181-200, 2009.

[25] Z. Yang, Z. Chang, Z. Hou, and S. Meffre, "Age, igneous petrogenesis, and tectonic setting of the Bilihe gold deposit, China, and implications for regional metallogeny," Gondwana Research, vol. 34, pp. 296-314, 2016.

[26] B. L. Mu, J. A. Shao, Z. Y. Chu, G. H. Yan, and G. S. Qiao, "Sm-Nd age and $\mathrm{Sr}, \mathrm{Nd}$ isotopic characteristics of the Fanshan potassic alkaline ultramafite-syenite complex in Hebei province," Acta Petrologica Sinica, vol. 17, no. 3, pp. 358-365, 2001.

[27] J. Shao, Y. Zhang, L. Zhang, B. Mu, P. Wang, and F. Guo, "Early Mesozoic dike swarms of carbonatites and lamprophyres in Datong area," Acta Petrologica Sinica, vol. 19, no. 1, pp. 93-104, 2003.

[28] B. Han, H. Kagami, and H. Li, "Age and Nd-Sr isotopic geochemistry of the Guangtoushan alkaline granite, Hebei province, China: Implications for early Mesozoic crust-mantle interaction in North China Block," Acta Petrologica Sinica, vol. 20, no. 6, pp. 1375-1388, 2004.

[29] J. H. Zhang, S. Gao, and W. C. Ge, "Geochronology of the mesozoic volcanic rocks in the great xing'an range, northeastern china: implications for subduction-induced delamination," Chemical Geology, vol. 276, no. 3-4, pp. 144-165, 2010.

[30] W.-L. Xu, F.-P. Pei, F. Wang et al., "Spatial-temporal relationships of Mesozoic volcanic rocks in NE China: constraints on tectonic overprinting and transformations between multiple tectonic regimes," Journal of Asian Earth Sciences, vol. 74, pp. 167-193, 2013.

[31] H.-G. Ouyang, J.-W. Mao, M. Santosh et al., "Geodynamic setting of Mesozoic magmatism in NE China and surrounding regions: perspectives from spatio-temporal distribution patterns of ore deposits," Journal of Asian Earth Sciences, vol. 78, pp. 222-236, 2013. 
[32] S.-J. Han, J.-G. Sun, L.-A. Bai et al., "Geology and ages of porphyry and medium- to high-sulphidation epithermal gold deposits of the continental margin of Northeast China," International Geology Review, vol. 55, no. 3, pp. 287-310, 2013.

[33] Q. Shu, Y. Lai, Y. Sun, C. Wang, and S. Meng, "Ore genesis and hydrothermal evolution of the baiyinnuoer zinc-lead skarn deposit, northeast china: Evidence from isotopes $(\mathrm{S}, \mathrm{Pb})$ and fluid inclusions," Economic Geology, vol. 108, no. 4, pp. 835-860, 2013.

[34] Q. Shu, Z. Chang, J. Hammerli, Y. Lai, and J. Huizenga, "Composition and evolution of fluids forming the baiyinnuoer $\mathrm{Zn}-\mathrm{Pb}$ skarn deposit, northeastern china: insights from laser ablation icp-ms study of fluid inclusions," Economic Geology, vol. 112, no. 6, pp. 1441-1460, 2017.

[35] H. P. Taylor Jr., “The application of oxygen and hydrogen isotope studies to problems of hydrothermal alteration and ore deposition," Economic Geology, vol. 69, no. 6, pp. 843-883, 1974.

[36] Y. M. Zhao, D. W. Wang, D. Q. Zhang et al., Ore Controlling Factors and Ore-Prospecting Models for Copper Polymetallic Deposits in Southeast Inner Mongolia, Seismological Press, Beijing, China, 1994.

[37] J.-M. Liu, Y. Zhao, Y.-L. Sun et al., "Recognition of the latest Permian to Early Triassic Cu-Mo mineralization on the northern margin of the North China block and its geological significance," Gondwana Research, vol. 17, no. 1, pp. 125-134, 2010.

[38] P. Kranidiotis and W. H. MacLean, "Systematics of chlorite alteration at the Phelps Dodge massive sulfide deposit, Matagami, Quebec," Economic Geology, vol. 82, no. 7, pp. 1898-1911, 1987.

[39] M. Cathelineau, "Cation site occupancy in chlorites and illites as a function of temperature," Clay Minerals, vol. 23, no. 4, pp. 471-485, 1988.

[40] E. C. Jowett, "Fitting iron and magnesium into the hydrothermal chlorite geothermometer," in GAC-MAC-SEG Joint Annual Meeting (Toronto 1991), vol. 16, p. A62, 1991.

[41] Y. F. Li, S. L. Sun, X. F. Bian, and X. Y. Gao, "Zircon LA-ICP-MS $\mathrm{U}-\mathrm{Pb}$ dating of the Biliutai intrusion in eastern Inner Mongolia," International Geology Review, vol. 59, no. z1, pp. 168-169, 2013.

[42] S. M. Sterner, D. L. Hall, and R. J. Bodnar, "Synthetic fluid inclusions. V. Solubility relations in the system NaCl-KCl-H2O under vapor-saturated conditions," Geochimica et Cosmochimica Acta, vol. 52, no. 5, pp. 989-1005, 1988.

[43] R. J. Bodnar, "Revised equation and table for determining the freezing point depression of $\mathrm{H} 2 \mathrm{O}-\mathrm{Nacl}$ solutions," Geochimica et Cosmochimica Acta, vol. 57, no. 3, pp. 683-684, 1993.

[44] R. N. Clayton, J. R. O’Neil, and T. K. Mayeda, "Oxygen isotope exchange between quartz and water," Journal of Geophysical Research: Atmospheres, vol. 77, no. 17, pp. 3057-3067, 1972.

[45] Z. Yong-Fei, "Calculation of oxygen isotope fractionation in anhydrous silicate minerals," Geochimica et Cosmochimica Acta, vol. 57, no. 5, pp. 1079-1091, 1993.

[46] Y. Matsuhisa, J. R. Goldsmith, and R. N. Clayton, "Oxygen isotopic fractionation in the system quartz-albite-anorthitewater," Geochimica et Cosmochimica Acta, vol. 43, no. 7, pp. 11311140, 1979.

[47] F. Ridolfi, A. Renzulli, and M. Puerini, "Stability and chemical equilibrium of amphibole in calc-alkaline magmas: An overview, new thermobarometric formulations and application to subduction-related volcanoes," Contributions to Mineralogy and Petrology, vol. 160, no. 1, pp. 45-66, 2010.
[48] R. H. Goldstein and T. J. Reynolds, Systematics of Fluid Inclusions in Diagenetic Minerals, vol. 31, Society for Sedimentary Geology Short Course Series, 1994.

[49] H. J. Stein and J. Hannah, "Movement and origin of ore fluids in Climax-type systems.”, Geology, vol. 13, no. 7, pp. 469-474, 1985.

[50] Y. Watanabe and J. W. Hedenquist, "Mineralogic and stable isotope zonation at the surface over the El Salvador porphyry copper deposit, Chile," Economic Geology, vol. 96, no. 8, pp. 1775-1797, 2001.

[51] A. C. Harris and S. D. Golding, "New evidence of magmaticfluid-related phyllic alteration: Implications for the genesis of porphyry Cu deposits," Geology, vol. 30, no. 4, pp. 335-338, 2002.

[52] T. Ulrich, D. Günther, and C. A. Heinrich, "The evolution of a porphyry $\mathrm{Cu}-\mathrm{Au}$ deposit, based on LA-ICP-MS analysis of fluid inclusions: Bajo de la Alumbrera, Argentina," Economic Geology, vol. 96, no. 8, pp. 1743-1774, 2001.

[53] J. W. Hedenquist, A. Arribas Jr., and T. J. Reynolds, "Evolution of an intrusion-centered hydrothermal system: far southeastLepanto porphyry and epithermal $\mathrm{Cu}-\mathrm{Au}$ deposits, Philippines," Economic Geology, vol. 93, no. 4, pp. 373-404, 1998.

[54] R. H. Sillitoe, "Porphyry copper systems," Economic Geology, vol. 105, no. 1, pp. 3-41, 2010.

[55] C. Pudack, W. E. Halter, C. A. Heinrich, and T. Pettke, "Evolution of magmatic vapor to gold-rich epithermal liquid: The porphyry to epithermal transition at Nevados de Famatina, Northwest Argentina," Economic Geology, vol. 104, no. 4, pp. 449-477, 2009.

[56] E. Seedorff and M. T. Einaudi, "Henderson porphyry molybdenum system, Colorado: I. Sequence and abundance of hydrothermal mineral assemblages flow paths of evolving fluids, and evolutionary style," Economic Geology, vol. 99, no. 1, pp. 3-37, 2004.

[57] B. G. Rusk, B. J. Miller, and M. H. Reed, "Fluid-inclusion evidence for the formation of Main Stage polymetallic base-metal veins," Arizona Geological Society Digest, vol. 22, pp. 573-581, 2008.

[58] S. E. Drummond and H. Ohmoto, "Chemical evolution and mineral deposition in boiling hydrothermal systems.," Economic Geology, vol. 80, no. 1, pp. 126-147, 1985.

[59] J. W. Hedenquist and J. B. Lowenstern, "The role of magmas in the formation of hydrothermal ore deposits," Nature, vol. 370, no. 6490, pp. 519-527, 1994.

[60] R. O. Fournier, "Hydrothermal processes related to movement of fluid from plastic into brittle rock in the magmaticepithermal environment," Economic Geology, vol. 94, no. 8, pp. 1193-1211, 1999.

[61] M. T. Einaudi, J. W. Hedenquist, and E. E. Inan, "Sulfidation state of fluids in active and extinct hydrothermal systems: transitions from porphyry to epithermal environments," Society of Economic Geologists Special Publication, vol. 10, pp. 285-313, 2003.

[62] C. G. Cunningham, G. W. Austin, C. W. Naeser et al., "Formation of a paleothermal anomaly and disseminated gold deposits associated with the Bingham Canyon porphyry $\mathrm{Cu}-\mathrm{Au}-\mathrm{Mo}$ system, Utah," Economic Geology, vol. 99, no. 4, pp. 789-806, 2004.

[63] M. R. Landtwing, T. Pettke, W. E. Halter et al., "Copper deposition during quartz dissolution by cooling magmatichydrothermal fluids: The Bingham porphyry," Earth and Planetary Science Letters, vol. 235, no. 1-2, pp. 229-243, 2005. 
[64] K. Kouzmanov and G. S. Pokrovski, "Hydrothermal controls on metal distribution in porphyry $\mathrm{Cu}(-\mathrm{Mo}-\mathrm{Au})$ systems," Society of Economic Geologists Special Publication, vol. 16, pp. 573-618, 2012.

[65] T. M. Seward and H. L. Barnes, "Metal transport by hydrothermal ore fluids," in Geochemistry of Hydrothermal Ore Deposits, H. L. Barnes, Ed., pp. 435-486, John Wiley and Sons, New York, NY, USA, 3rd edition, 1997.

[66] S. M. F. Sheppard, R. L. Nielsen, and H. P. Taylor Jr., "Hydrogen and oxygen isotope ratios in minerals from porphyry copper deposits," Economic Geology, vol. 66, no. 4, pp. 515-542, 1971.

[67] T. Baker, "Emplacement depth and carbon dioxide-rich fluid inclusions in intrusion-related gold deposits," Economic Geology, vol. 97, no. 5, pp. 1111-1117, 2002.

[68] J. Vallance, L. Fontboté, M. Chiaradia, A. Markowski, S. Schmidt, and T. Vennemann, "Magmatic-dominated fluid evolution in the Jurassic Nambija gold skarn deposits (southeastern Ecuador)," Mineralium Deposita, vol. 44, no. 4, pp. 389-413, 2009.

[69] M. W. Schmidt, "Experimental constraints on recycling of potassium from subducted oceanic crust," Science, vol. 272, no. 5270, p. 1927, 1996.

[70] D. Selby, B. E. Nesbitt, K. Muehlenbachs, and W. Prochaska, "Hydrothermal alteration and fluid chemistry of the Endako porphyry molybdenum deposit, British Columbia," Economic Geology, vol. 95, no. 1, pp. 183-201, 2000.

[71] S. Ludington, "Low-fluorine Stockwork Molybdenite Deposits," US Geological Survey Open-File 1215, US Geological Survey, Reston, Va, USA, 2009.

[72] R. D. Taylor, J. M. Hammarstrom, N. M. Piatak, and R. R. I. Seal, "Arc-related porphyry molybdenum deposit model," U.S. Geological Survey Scientific Investigations 2010-5070, 2012. 

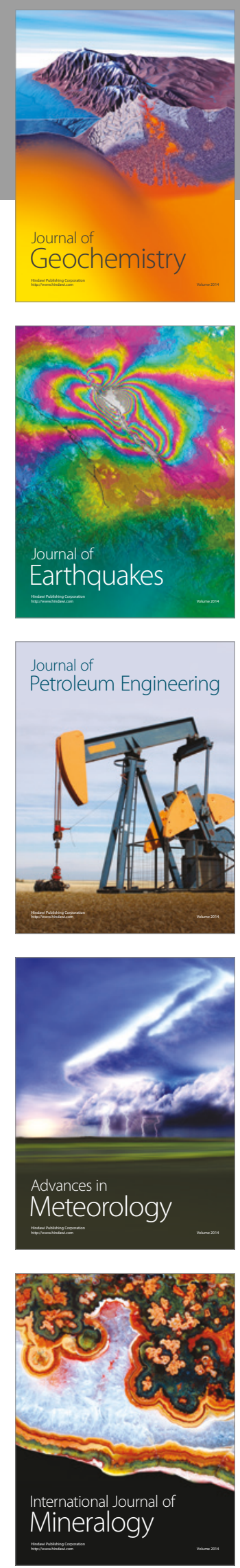
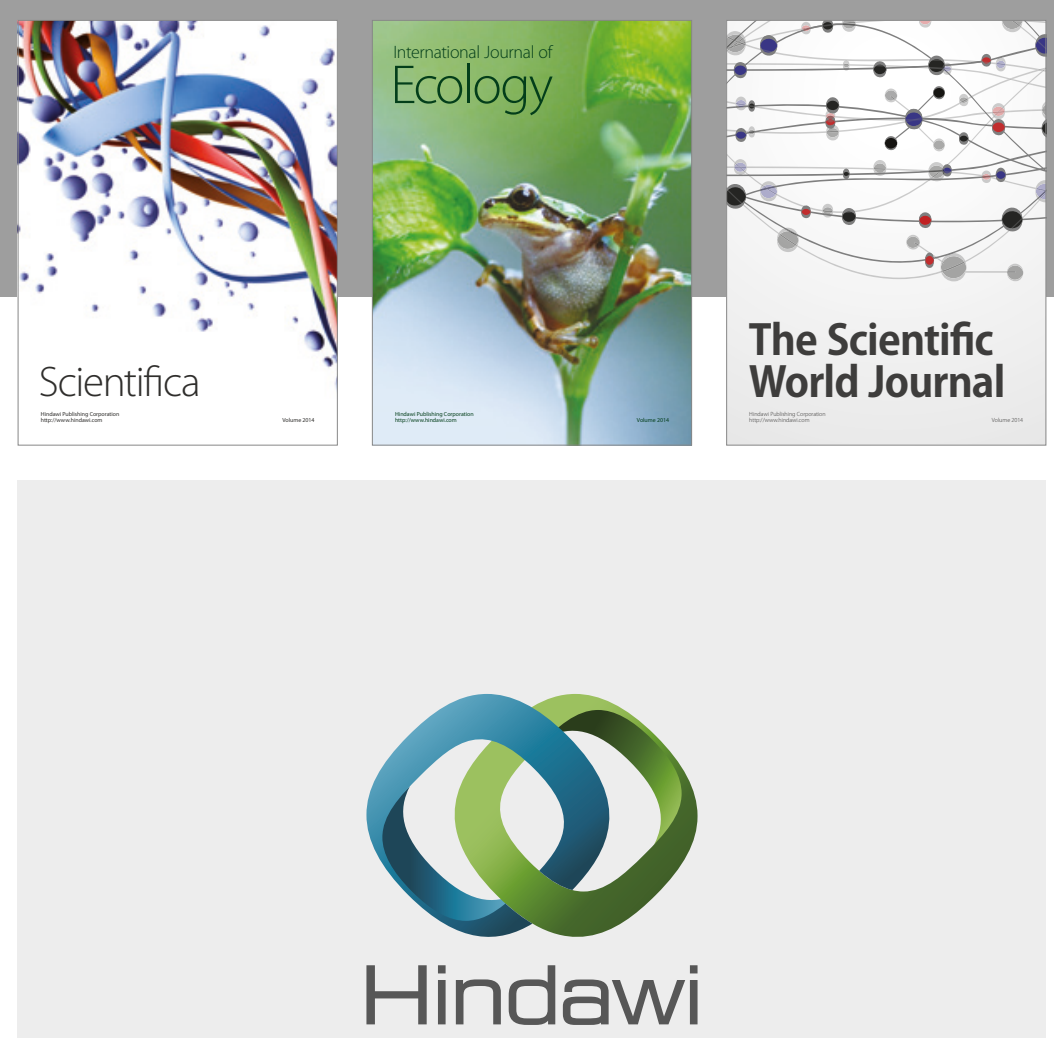

Submit your manuscripts at

https://www.hindawi.com
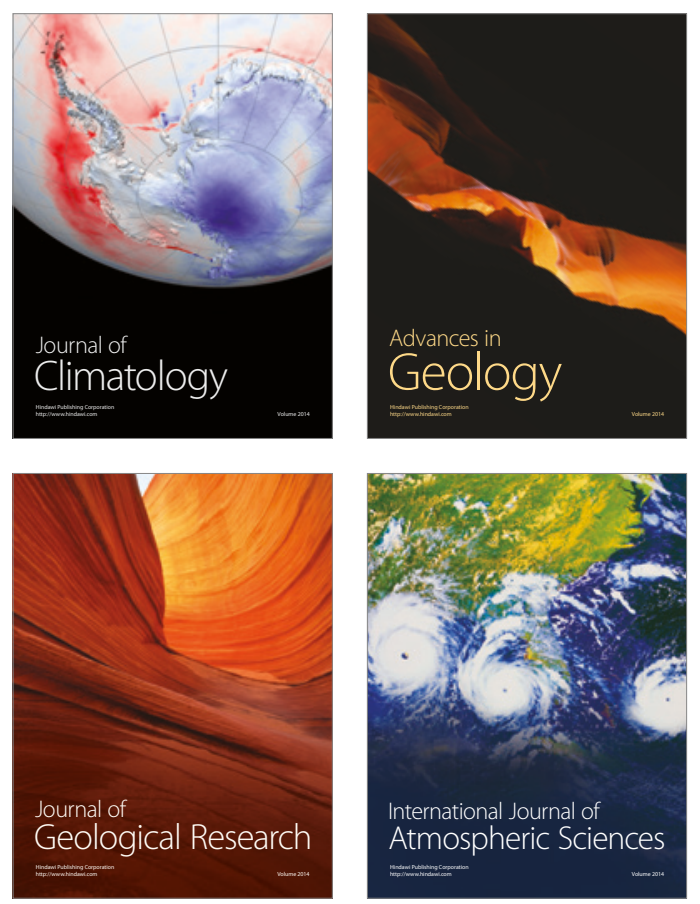

The Scientific

World Journal
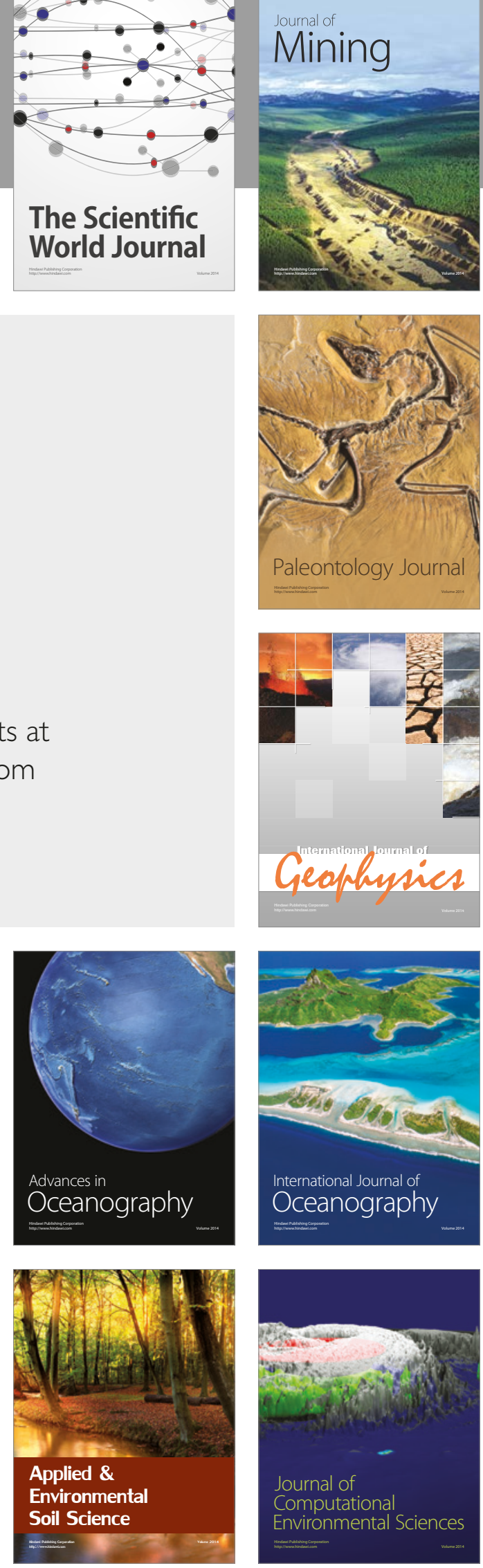